\title{
EXPORT PERFormance OF THE ASIAN Miracle Economies: THE ROLE OF INNOVATION AND PRODUCT VARIETY
}

\author{
James B. Ang, ${ }^{* a}$ Jakob B. Madsen $^{\mathrm{b}}$ and Peter E. Robertson ${ }^{\mathrm{c}}$ \\ ${ }^{a, b}$ Department of Economics, Monash University \\ ${ }^{c}$ Business School, The University of Western Australia
}

This version: 27 July 2013

\begin{abstract}
This paper argues that traditional export models, in which exports are driven by price competitiveness and income of trade partners, fall short of explaining the market increase in exports in the Asian miracle economies (China, India, Korea, Japan, Singapore and Taiwan) in the post-WWII period. A model showing that exports are driven by innovations, the innovative competitiveness, demand, and price competitiveness is estimated for the Asian miracle economies during the period 1953-2010. External instruments are used for innovations, innovation competitiveness and price competitiveness. The regression results demonstrate that the innovations stock and competitiveness have been important determinants for the export success of these economies.
\end{abstract}

JEL Classifications: O30, O40

Keywords: Asian Miracle Economies, exports, innovation.

\footnotetext{
* Corresponding author: Department of Economics, Monash University, 900 Dandenong Road, Caulfield East, Vic 3145 Australia. E-mail: James.Ang@monash.edu.

Acknowledgements: Helpful comments and suggestions from the co-editor (John Ries) and two anonymous referees, which have led to a much improved version of the paper, are gratefully acknowledged. The authors would also like to thank Stoja Andric, Cong Wang and Sanjesh Kumar for their research assistance as well as Laura Puzzello and Bruce A. Blonigen for sharing their data on regional trade agreements. Financial support from the Australian Research Council (Discovery Projects), including grants DPO877427 (Jakob Madsen), DP0984811 (Jakob Madsen and Peter Robertson) and DPO121030326 (James Ang and Jakob Madsen), is gratefully acknowledged.
} 


\section{Introduction}

An important feature of the economic success of the Asian miracle economies (China, India, Japan, Korea, Singapore and Taiwan), henceforth the AM economies, has been their ability to sustain high export growth over a long period of time. Their export performance has been remarkable. Exports as a percentage of GDP grew more than 500\% in the period 1970-2010 for China and 72\% for the AM economies as a whole. This stands in sharp contrast to the experience of the sub-Saharan African economies where exports grew by only $1.5 \%$ over the same period (see the data appendix for data sources). Given that changes in external conditions have not been much more favorable for the AM economies than for the African economies, this suggests that we need to look beyond simple explanations of costs competitiveness and external demand.

Despite the unprecedented export growth performance of the AM countries over a very short time span and the considerable attention given to this issue in the literature, very little research has attempted to examine the underlying approximate causes of their strong export growth. Redding and Venables (2003) and Jongwanich (2010) are among the few exceptions. Specifically, Redding and Venables (2003) decompose export growth into the contribution of foreign market access and the improvement of supply conditions whereas Jongwanich (2010) estimates an imperfect substitution model in which export volume is taken as a function of real exchange rates, world income, production capacity and foreign direct investment.

Furthermore, trade and growth theory has evolved considerably in the last two decades and offers a number of alternative explanations for the export success of the AM economies. These include explanations based on governance, infrastructure, educational attainment and explanations based on $\mathrm{R} \& \mathrm{D}$, innovation, increasing specialization, and new goods. With respect to trade and growth in particular, however, an extensive literature following Grossman and Helpman (1991) and Helpman and Krugman (1985) emphasizes the importance of new goods and trade in intermediate goods as sources of growth. In these models trade in intermediate varieties of goods generates specialized inputs into production processes. But very little evidence exists on how these theoretical links explain the trade booms in the AM countries.

In this paper we aim to evaluate whether these theories that emphasize the importance of new goods and innovation in explaining trade, can help understand the proximate sources of the massive export booms in the AM economies. Specifically we aim to exploit the extensive international data that exists on trademarks, product designs, patent stocks and R\&D investment to see if these measures of innovations may have played a major role. We supplement this data with other measures such as 
governance and institutional measures to give a more comprehensive investigation of complementary explanations for the growth in trade of the AM economies, and consider differences between the early miracle economies such as Japan and Korea, and the newly emerging giants of China and India. The research in this paper is the first to study exports in the AM economies based on an innovation and growth framework.

To motivate our empirical model we first briefly derive a standard trade-in-varieties model in which innovations and the innovative competitiveness are incorporated into a traditional income and price model of exports. The model goes one step further than the traditional trade theories where exports are driven primarily by foreign income and price competitiveness (see, for critical assessments of traditional income-based models, Krugman (1989), Fagerberg (1994, 1996), Wolff (1995), Anderton (1999a, b), Fagerberg et al. (2007) and Madsen (2008b)). The model is tested using data for stock of innovations, innovative competitiveness, price competitiveness, and foreign income for six AM economies over the period 1953-2010.

Empirically, the model is in the same spirit as the papers that have integrated R\&D into trade models for OECD countries. In an influential paper, Fagerberg (1988) shows that innovation competitiveness, measured by relative $R \& D$ expenditure and patent counts, has important effects on aggregate exports for OECD countries. These results have been extended and supported by the findings of Amendola et al. (1993), Magnier and Toujas-Bernate (1994) and Amable and Verspagen (1995) based on pooled cross-section and time-series data for OECD countries. Using sectoral data, a number of studies have also examined the effects of innovation competitiveness on sectoral market shares and trade (see, e.g., Greenhalgh (1990), Greenhalgh et al. (1994), Magnier and Toujas-Bernate (1994), Fagerberg (1997), Anderton (1999a, b) and Carlin et al. (2001)).

The paper proceeds as follows. The theoretical model, which is used to motivate the empirical analysis, is derived in the next section and empirical estimates are carries out in Section 3. Section 4 presents robustness tests and further empirical analysis and Section 5 concludes.

\section{A Simple Model of Research Activity and Trade}

In this section we first illustrate the relationship between R\&D investment and export supply that arises in a standard product variety model. The model shows that innovations can affect exports through either cost savings on existing goods or in the form of discovery of new goods. Though very standard the model provides a parsimonious link between traditional empirical export models, such as surveyed in 
Goldstein and Khan (1985) that focus on income and price as determinants of exports, and the newer theories that focus on the role of innovations in the growth process.

\subsection{Demand for intermediate goods.}

We consider a representative firm in country, $i$, that produces final goods using labor, $L_{i}$, and intermediate goods designated by source country $j, x_{i j}$. Following Ethier (1982) and Helpman and Krugman (1985) we assume further that $i$ has a production function given by:

$$
Y_{i}=A L_{i}^{1-\alpha} z_{i}^{\alpha}
$$

where $A$ is technology; $z_{i} \equiv\left(\sum_{j=1}^{M} N_{j} x_{i j}^{\alpha}\right)^{1 / \alpha}$ is an aggregate intermediate input index, where $M$ is the number of countries in the world economy and $N_{j}$, is the number of patented intermediate products produced in country $j$, and $\alpha<1$ is a parameter. ${ }^{1}$ Thus as in the growth literature, such as Romer (1990) and Rodrik (1996), the $z_{i}$ is an index of productivity in the final goods sector in $i$, which in turn is a function of the number of varieties of intermediate goods used in country $i$. Likewise $N_{j}$, is an index of the research and development intensive output of country $j$. Hence in this simple Ethier-Romer framework, the productivity of final goods and the innovation intensity of exports are both directly linked to the number of traded intermediate varieties

The firm's input demand choice for a unit of intermediate goods is

$$
x_{i j}=\alpha\left(\frac{Y_{i}}{P_{i}}\right)\left(\frac{p_{j}}{P_{i}}\right)^{-\sigma}
$$

where $\sigma=1 /(1-\alpha)>1$ and $P_{i} \equiv\left(\sum_{j=1}^{M} N_{j} p_{j}^{1-\sigma}\right)^{1 /(1-\sigma)}$ is a price index for aggregate intermediate input $z_{i}$. Eq. (2) is a standard import demand equation which is widely used for example in the gravity and trade literature (Anderson, 2011). It shows that country j’s exports depend on the total intermediate demand

\footnotetext{
${ }^{1}$ This specification assumes that all goods sold in each country $i$, sourced from country $j$, have the same price. This will be true in equilibrium and follows from the assumption that, within each source country, firms face the same marginal cost of production for intermediate goods.
} 
effect from the destination country, $\alpha Y_{i} / P_{i}$, and price competitiveness effect $\left(p_{j} / P_{i}\right)^{-\sigma}$. If $\sigma>1$ then a reduction in the relative price of country $j$ 's intermediate goods exports relative to other countries will result in an increase in export sales for country $j .{ }^{2}$

\subsection{R\&D Sector}

We wish to investigate the role of research and development in the exporting country, and in particular on its supply of exports. Following, for example, Romer (1990), and Grossman and Helpman (1991), and more recent models such as Gustafsson and Segerstrom (2010), we assume intermediateproduct-producing firms design and patent new intermediate goods under conditions of monopolistic competition. We assume that an intermediate good produced in country $j, x_{j}$ costs $\gamma_{j} \geq 1$ units of output to produce. Producer j's profits at a point in time are given by the profit per unit sold to firms in all $M$ countries. Profits are given by $\pi_{j}=\left(p_{i j}-\gamma_{j}\right) \sum_{i=1}^{M} x_{i j}$. It can be shown that the profit maximizing price for all goods produced is equal to $p_{i j}=p_{j}=\gamma_{j} / \alpha$. Using this equilibrium condition, multiplying both sides of (2) by $N_{j}$, and taking logarithms gives a simple linear export equation that depends on import demand and export supply parameters,

$$
\ln X_{i j}=(1+\sigma) \ln \alpha+\ln \left(Y_{i} / P_{i}\right)-\sigma \ln \left(\gamma_{j} / P_{i}\right)+\ln N_{j}
$$

where $X_{i j} \equiv x_{i j} N_{j}$ is total exports from $j$ to $i$.

Eq. (3) summarizes the impact of R\&D in the exporting country on its exports. Clearly $\partial \ln X_{i j} / \partial \ln N_{j}>0$ and $\partial \ln X_{i j} / \partial \ln \gamma_{j}<0$. Hence there are two types of technological change that can increase country j's exports. Any reduction in $\gamma_{j} / P_{i}$, which implies increasing the competiveness of its $\mathrm{R} \& \mathrm{D}$ sector. In addition there is a size effect through expanding the number of varieties the export country produces, $N_{j}$.

Traditional empirical models of export behavior, as in Goldstein and Khan (1985), include price competitiveness as an argument but not knowledge or R\&D. Eq. (3) shows, however, that price competitiveness may reflect elements of $\mathrm{R} \& \mathrm{D}$ or knowledge competitiveness, to the extent that they

\footnotetext{
${ }^{2}$ It can be shown that this term is related to the share of country $j$ 's exports in country i's total imports Specifically $\left(p_{j} / P_{i}\right)^{-\sigma}=x_{i j} / z_{i}$ and $N_{j}\left(x_{i j} / z_{i}\right)^{(\sigma-1) / \sigma}=x_{j}^{\alpha} N_{j} /\left(\sum_{j} x_{j}^{\alpha} N_{j}\right)=p_{j} x_{i j} N_{j} / \alpha Y_{i}$, which is the share of imports from country $j$ in country i's total spending on intermediate inputs.
} 
reduce the relative price of intermediate traded goods, $\gamma_{j} / P_{i}$. This type of R\&D might be thought of as product development through imitation, which is a feature innovation in transitional and developing countries.

Nevertheless trade theory suggests both incremental imitation type knowledge and the development of new goods are important (Grossman and Helpman, 1991; Gustafsson and Segerstrom, 2010). Moreover innovation in low wage economies often takes the form of product and process quality upgrades. Such changes may not easily be captured in price data since they involve changes in the quality of components.

Moreover, Puga and Trefler (2010) show that innovation in new goods, such as an expansion in varieties, $N_{j}$, is becoming increasingly important for AM countries especially Malaysia, Thailand, India, the Philippines and China. Thus, including measures of innovation activities such as R\&D spending and knowledge stocks, as indicated by Eq. (3), is an important factor to consider in our empirical investigation into the AM countries export performance. ${ }^{3}$

\section{Empirics}

The model in the previous section suggests that we can augment traditional export models based on trade-weighted income (TWI) and price competitiveness by including supply side measures of the innovative activity. Specifically Eq. (3) suggests the following empirical counterparts:

$$
\begin{gathered}
\ln E X_{i t}=\alpha_{0}+\alpha_{1} \ln T W I_{i t}+\alpha_{2} \ln P_{i t}^{e x}+\alpha_{3} \ln S T K_{i t}^{x}+C D_{i}+\varepsilon_{1, i t}, \\
\ln E X_{i t}=\beta_{0}+\beta_{1} \ln T W I_{i t}+\beta_{2} \ln P_{i t}^{e x}+\beta_{3} \ln C O M_{i t}^{x}+C D_{i}+\varepsilon_{2, i t}, \\
x=R D, P S, T M, P D \text { or } P C
\end{gathered}
$$

where $E X$ is the total export volume, TWI is trade weighted real income of export destination countries, $P^{e x}$ is export price competitiveness, $C D$ represents a set of country dummies, $\varepsilon$ is a stochastic error term, $C O M^{x}$ is innovative competitiveness for the innovative variable $x, S T K^{x}$ is domestic innovation stock for the innovative variable $x$. Innovation knowledge and the innovative competitiveness are based on R\&D stock $(R D)$, stock of patent applications $(P S)$, stock of trademarks (TM), product designs $(P D)$ and their first principal component $(P C)$.

\footnotetext{
${ }^{3}$ The number of varieties, $N_{j}$ and the cost of intermediate goods, $\gamma_{j}$, may be related in general equilibrium, but need not be, as shown for example in Rodrik (1996). Here we follow the gravity trade literature, as for example in Baier and Bergstrand (2001), by treating $N_{j}$ as exogenous for the purpose of our empirical model.
} 
The model is estimated using panel time series data for the AM countries in the period 1953-2010. Innovation knowledge stock and innovation competitiveness are included separately in the trade model because they are highly correlated. The correlation between the two variables range between 0.73 and 0.83, suggesting that most of the identifying correlation in innovation competitiveness comes from the variation in the innovation stock among the AM economies. A financial crisis dummy variable (1997/98 $=1$ and 0 otherwise) was initially included in the regressions for Japan and Korea; however, it was dropped from the final regressions because it was insignificant.

Knowledge is based on various measures of innovations such as $\mathrm{R} \& \mathrm{D}$, patents, trademarks, and product designs because they each represent different attributes of the innovative activity. In addition to using the individual measures of innovation stock, these indicators are also combined into a composite index using the method of principal component analysis which seeks to find pattern in data of high dimension as in our case. The principal component analysis is a powerful way of highlighting differences and similarities in the data and compresses the number of dimensions in the data substantially without the loss of information. In the principal component analysis all variables are first standardized so that they represent deviations from the means divided by the standard deviation to ensure that they have the same mean and standard deviation. Using information from the leading eigenvector from the decomposition of the covariance matrix of the variables as weights, the resulting composite index is then constructed as a linear combination of the original innovation indicators.

The principal component is, particularly, suited for the analysis in this paper because of a high correlation between the innovation variables. The composite index for innovation stock is significantly positively correlated with all indicators of innovation stock, with correlation coefficients ranging from 0.77 (product design stock) to 0.95 (trademarks stock), thus suggesting that it is an appropriate measure of overall innovation stock. For innovation competitiveness stock, the correlation coefficients range from 0.60 (R\&D competitiveness stock) to 0.90 (trademarks competitiveness stock). The empirical estimates are very similar if the simple average is used instead.

\subsection{Estimators}

Eqs. (4) and (5) are estimated using the instrumental-variable fixed-effect (IV-FE) estimator. This procedure corrects for possible endogeneity due to reverse causality, measurement errors and omitted variable bias, and is used as our benchmark estimator. To provide robustness check for the results, the above equations are also estimated using the vector-error correction model (VECM) and the group-mean panel fully-modified (FM-OLS) estimator. The VECM is a dynamic system approach treats all underlying variables as endogenous. Given that the OLS estimator is asymptotically biased and inconsistent, we use 
the between-dimension FM-OLS estimator of Pedroni (2000), which applies semi-parametric correction to the OLS estimator to eliminate bias due to endogeneity of the regressors. A detailed description of these procedures is provided in the appendix (Section A).

\subsection{Identification}

Instruments are used for the innovative competitiveness, innovation knowledge stock, and price competitiveness as the parameter estimates are likely to be influenced by endogeneity and measurement errors. For price and the innovative competitiveness this implies that instruments need to be created for the home country as well as competitors, where the competitors and not just the AM economies but also the western OECD countries. Altogether this adds up to 26 countries, where the countries are listed in the first paragraph of Section 3.3. The required large number of instruments may partly explain why external instruments are rarely, if ever, used in empirical models of foreign trade. In this subsection we first discuss the reason why it is necessary to use an instrument strategy and then discuss the instruments that are used for identification.

There are several reasons why an OLS estimation strategy may lead to biased coefficient estimates. First, for innovation stock and innovation competitiveness the coefficient estimates may be biased in OLS estimates due to unobserved country characteristics that are correlated with the included covariates. For example, exports in the AM countries' may partly have been fuelled by a more marketoriented and open approach to foreign trade and innovation that have simultaneously enhanced productivity growth and exports. Second, a slow export growth, for example, may be associated with an increasing unemployment rate that, in turn, reduces wage growth through the Philips curve effect and, consequently, leads to an improvement in export price competitiveness. Third, an increasing demand for exports will simultaneously increase the price and volume of exports; thus establishing a perverse relationship between exports and price competitiveness. Fourth, Madsen (1999) shows formally that export price elasticities are asymptotically biased towards -1 and not zero, as conventionally believed, due to measurement errors in decomposing export values into prices and quantities. Export volume is almost always measured in units of weight, which imply that a transition from exporting, say, cast iron to selling high technological and sophisticated products, ceteris paribus, reduces export volume even if quality adjusted exports is unaltered and, by default, increases prices proportionally. Thus, although price competitiveness has not been reduced the decompositional measure error will force the coefficient of price competitiveness towards -1 .

Four external instruments are used for identification. Real food prices and unionization are used as instruments for price competitiveness while cohort infant mortality and temperature are used as 
instruments for innovation stock and innovation competitiveness. Food prices and unionization (union members divided by employment) are used as instruments for export price competitiveness, $P^{e x}$, since output prices, and hence export prices, are predominantly driven by markups on unit labor costs, which in turn are determined by wage push factors through the Phillips or the wage curve. Prices of food deflated by consumer prices and unionization are considered to be among the most important wage push factors (see Bruno and Sachs, 1985; Madsen, 1998b, 2009a). Although unemployment is a central variable in the Phillips curve it is not included in the instrument set because it, through the natural rate framework, is determined by wage push factors and, as such, is not exogenous (Madsen 2009a).

Relative food prices affect output prices directly because wages, formally or informally, are indexed to consumer prices. The food price shocks in the 1970s are examples of commodity price shocks that, in conjunction with increased unionization, triggered inflation during the 1970s and in the first half of the 1980s. Measuring the wage pushiness by the wage gap (the real wage in excess of labor's marginal productivity), Bruno and Sachs (1985) show that there is a close relationship between the wage gap and union membership rates. Thus, pushy unions are associated with high union membership, as demonstrated by a marked increase in union membership prior to and during the wage explosion period in Europe in the 1970s (Bruno and Sachs, 1985; Madsen, 1998b). Conversely, wage explosions were not experienced in countries such as US, Singapore and Switzerland where unionization did not increase. Over the past two decades union membership rates have slipped in the non-AM economies while they have increased in China, Singapore and India and decreased slowly or stagnated in the other AM countries; thus, giving large identifying variations in the data.

Taxes (tariffs, direct taxes and indirect taxes) and real oil prices were initially included as instruments for price competitiveness. Taxes are, in some union models, also considered potential wage push factors since workers may seek compensation through higher wages to cover the deterioration of their real disposable income in response to higher taxes (Goerke, 2002). Bruno and Sachs (1985) argue that real oil prices are important wage push factors because of their effect on cost of living. However, we excluded taxes and real oil prices from our instrument set because they were insignificant and because we wanted to keep the first-round regressions as parsimonious as possible. Furthermore, taxes are not entirely exogenous but influenced by the state of the economy. The insignificance of taxes is not surprising since many AM economies have first recently introduced a tax system that is comparable with the system in the mature OECD countries and because higher taxes do not necessarily drive wages up in some union based models (see, for example, Goerke, 2002). The insignificance of real oil prices may reflect an intricate system of fuel taxes and subsidies and, more importantly, that oil price shocks, in the absence of taxes 
and subsidies, will affect all countries in the world almost equally and, therefore, keep the price competitiveness unaffected.

Relative food prices as well as union membership rates are likely to be exogenous. Relative food prices are determined by domestic and international food supply shocks, which are heavily influenced by exogenous weather conditions such as droughts and floods. Since the composition of food consumption differs across nations and a large fraction of food is domestically grown, food prices, in contrast to oil prices, move quite distinctively across countries. Regarding union membership there is a large literature on determinants of unionization showing that social customs, pro-union attitudes, and the fraction of the electorate supporting left-wing parties are crucial determinants of unionization (Goerke and Pannenberg, 2004). This explains the intuition that the wage explosion in the 1970s was very much influenced by a pro-labor social movement that was very strong in many western countries. As social customs and political attitudes are unlikely to influence exports through channels other than unionization the exclusion restriction that union membership influences exports through price competitiveness is highly likely to be satisfied.

The stock of innovations and innovation competitiveness are instrumented using temperature and cohort infant mortality rates as primary instruments (the wage push factors are also used as instruments since we are using 2SLS). Temperature anomaly serves as a potentially good instrument in that persistent low temperatures may create hunger and starvation in low income countries, such as the AM economies during the 1950s. A small reduction in temperature is often associated with a reduction in the duration of light during the year and, consequently, with a reduction in the growing periods of crops and pastures and land cannot be cultivated at high altitudes. Malanima (2006), for example, finds climate to have been influential for living standards in Europe during the past millennium. Temperature can potentially influence innovations in that the $R \& D$ is likely to be the first to suffer if income is reduced due to weather conditions.

Cohort infant mortality, $\Phi$, is a potential excellent instrument for innovations because, as explained below, it proxies cognitive ability of the working population conditioned on their health experience during their fetal life and infanthood noting that most of the cognitive development reached at adulthood occurs in utero and first years of life (Eppig et al., 2010; Madsen, 2013). Following Madsen (2013) cohort infant mortality is constructed as:

$$
\Phi_{t}=\left(\sum_{j=15}^{64} \text { Pop }_{j t} I M_{t-j}\right)\left(\text { Pop }_{15-64}\right)^{-1}, \quad j=15,16, \ldots 64
$$


where $\mathrm{Pop}_{j t}$ is size of the population in age cohort $j$ at time $t, P_{0 p_{15-64}}$ is the population of working age, and $I M_{t-j}$ is the infant mortality rate at period $t-j$. This equation shows that the working population cohort at time $t$ comes from a birth cohort in which the average infant mortality was $\Phi$. For the 25 year old cohort, for example, the $\Phi$ is the infant mortality of the population 24 years earlier. Since the estimation period commences in 1953 cohort infant mortality is constructed from data spanning 1890-2010.

Why is cohort infant mortality so important for innovations? The key here is that cognitive skills, which are vital for knowledge production, have been shown to be highly sensitive to health insults in utero and early years of life; particularly health insults such as parasitic and infectious disease (Eppig et al., 2010). Since most of the brain's development occurs from half way through pregnancy until the child reaches the age of two, this period is by far the most important for cognitive development and health capital in general (Niehaus et al., 2002; Almond and Currie, 2011). Adequate development of the brain during infancy requires a sufficient supply of energy, essential micro nutrition and oxygen, noting that the brain in a new-born baby claims at least 87 percent of the body’s energy budget (Holliday, 1986). Numerous studies have shown that parasitic and infectious diseases significantly impair cognitive ability and development due to loss of appetite, mobilization of the immune system, diarrhoea, and, loss of tissues to parasites (see Watkins and Pollitt, 1997; Jardim-Botelho et al., 2008).

Increasing cognitive skills, as signified by decreasing cohort infant mortality, is likely to have been a potential important determinant of the increasing innovative activity in our country sample in the period 1953-2010. In this context is important to note that IQ’s are not fixed over time and across nations as commonly and implicitly assumed in the literature on endogenous growth and human capital. The psychological literature finds that IQ's in the western world has on average increased by approximately three points in each decade over the past century (Lynn and Vanhanen 2006); thus it has significantly increased the research potential of western countries since 1953. Cohort infant mortality data are used as proxies for IQ following Madsen (2013) because the available IQ data are highly fragmented and no continuous macro data exist over a long time-span for the sample countries used here.

Cohort infant mortality is likely to be exogenous since it is computed from infant mortality rates in the distant past and it is unlikely that factors that caused the decline in infant mortality rates have simultaneously impacted on exports with a lag. The decline in infant mortality is predominantly due to improved sanitation, introduction of water supply and sewage infrastructure and pasteurization of cow's milk (Lee, 2007; Castilho and Barros Filho, 2010). These factors have improved quite independently of promotion of exports and modernization. Pasteurization and the an extensive expansion of the sewage and water supply infrastructure, for example, started in the late $19^{\text {th }}$ and early $20^{\text {th }}$ centuries Europe and the US (Lee, 2007; Castilho and Barros Filho, 2010); however, the level of per capita income was quite 
different across these countries at that period and, more importantly, the trade, in proportion to GDP, contracted or stagnated in the period 1914-1960 during infant mortality decreased the most (Madsen, 2009b).

The instruments for price and innovation competitiveness are constructed using bilateral weights in the same way and the non-instrumented innovation and price competitiveness as shown explicitly in the next sub-section.

\subsection{Data}

The trade weighted income for country $i$ refers to the GDP of the destination country $j$ weighted by the share of nominal exports from country $i$ to country $j$ at year $t$ as follows:

$$
T W I_{i t}=\sum_{j=1}^{26} \frac{E x_{j i t} Y_{j t}}{E x_{i t}}, \quad i \neq j,
$$

where $E x_{j i}$ is nominal exports from home country $i$ to country $j$ in common currency (USD), $E x_{i}$ is total nominal exports of country $i$ in common currency, and $Y j$ is real income of the destination country $j$. Data for the following 26 countries are used to construct the index: Canada, the US, Japan, Australia, New Zealand, Austria, Belgium, Denmark, Finland, France, Germany, Greece, Ireland, Italy, the Netherlands, Norway, Portugal, Spain, Sweden, Switzerland, the UK, Singapore, Taiwan, South Korea, India and China.

Innovation stock is measured by patent stock, real R\&D stock, stock of trademarks and stock of product designs, following the predictions of innovation-based models. While R\&D and patents are more related to quality-improving innovation, trademarks and product designs are more closely associated with product variety. Following Coe and Helpman (1995), R\&D expenditure is deflated by an unweighted average of the economy-wide value-added price deflator and an hourly earnings index. The stock of knowledge is constructed using the perpetual inventory method with a 15\% depreciation rate. The initial stock of knowledge is inferred from the flow of knowledge by dividing initial flow of knowledge by the sum of the rate of depreciation (15\%) and the average annual geometric growth rates in real knowledge flow over the entire data period. Patents, trademarks, and product design data are based on the number of applications filed by domestic residents. Applications instead of grants data are used because the granting period varies substantially over time and across countries (Griliches, 1990).

Price competitiveness is constructed using bilateral weights as follows:

$$
P_{i t}^{e x}=P_{i t} / \sum_{j=1}^{26} \frac{E x_{j i t} e_{i j t} P_{j t}}{E x_{i t}}
$$


where $P_{i}$ and $P_{j}$ are export unit values (export prices) of country $i$ and $j$, respectively, $e_{i j}$ is the bilateral exchange rate between country $j$ and $i$, where an increase in $e$ signifies a currency depreciation of country $i$ vis-à-vis country $j .{ }^{4}$ An increase in $P^{e x}$ is associated with a deterioration of country $i$ 's price competitiveness.

Technological competitiveness is also based on bilateral trade weights and is constructed as follows:

$$
\operatorname{Com}_{i t}^{x}=S_{i t}^{x} / \sum_{j=1}^{26} \frac{E x_{j i t} S T K_{j t}^{x}}{E x_{i t}}
$$

where $S T K^{x}$ is the stock of innovations ( $x=\mathrm{RD}$, PS, TM, or PC). An increase in the index is associated with an improvement in the innovative competitiveness.

Table 1: Average annual percentage growth rate of all variables (1953-2010)

\begin{tabular}{llllllll}
\hline Variable & China & India & Japan & Korea & Singapore & Taiwan & AM \\
\hline Export volume $(E X)$ & 11.92 & 6.48 & 9.16 & 18.52 & 10.17 & 10.45 & 11.12 \\
Trade weighted income $(T W I)$ & 3.51 & 3.43 & 4.41 & 4.68 & 3.77 & 5.44 & 4.21 \\
Export price competitiveness $\left(P^{e x}\right)$ & -1.98 & 0.33 & 2.01 & -4.85 & 0.98 & -1.26 & -0.80 \\
R\&D stock $\left(S T K^{R D}\right)$ & 10.20 & 10.42 & 7.74 & 8.87 & 12.80 & 11.94 & 10.33 \\
Patent stock $\left(S T K^{P S}\right)$ & 16.68 & 4.21 & 6.21 & 9.26 & 10.19 & 10.71 & 9.54 \\
Trade mark stock $\left(S T K^{T M}\right)$ & 16.50 & 5.49 & 3.25 & 11.56 & 4.46 & 8.51 & 8.29 \\
Product design stock $\left(S T K^{P D}\right)$ & 29.93 & 0.04 & 3.63 & 8.81 & 1.74 & -0.08 & 7.35 \\
R\&D stock competitiveness $\left(C O M^{R D}\right)$ & 6.83 & 7.15 & -2.04 & 4.51 & 9.05 & 7.09 & 5.43 \\
Patent stock competitiveness $\left(C O M^{P S}\right)$ & 15.24 & 1.87 & 1.33 & 4.53 & 9.96 & 4.66 & 6.26 \\
Trade mark stock competitiveness $\left(C O M^{T M}\right)$ & 3.67 & 1.17 & -2.21 & 5.90 & -0.09 & 3.15 & 1.93 \\
Product design stock competitiveness $\left(C O M^{P D}\right)$ & 9.09 & -2.28 & 0.14 & 4.04 & -0.88 & -4.54 & 0.93 \\
\hline Notes
\end{tabular}

Notes. the growth rates are geometric averages. The AM figures reflect the unweighted averages of the six AM economies.

Table 1 presents the geometric growth rates of all variables used in the regressions. The data confirm that the AM countries have experienced marked increases in export volume and that these growth rates have been associated with equally impressive increases in the innovation stock variables as well as knowledge competitiveness. The approximately $10 \%$ increase in $\mathrm{R} \& \mathrm{D}$ and patent stock has, on average, resulted in a remarkable 6\% (approximate) improvement in knowledge competitiveness. This implies that

4

We initially considered a multilateral competitiveness index which is based on the market shares of competitors in the export markets, including the market share of the domestic producer (see, for derivation, Madsen, 1998). The advantage of such a multilateral index is that it also allows for competition from exporters from other export markets selling in country $i$ 's export market. However, it was not possible to construct such an index here because the sales revenue of domestic manufacturing producers are not available for most of the countries in the sample. 
R\&D and patent stock among the AM economies have increased substantially. The increase exceeds that of the mature OECD economies and may potentially explain the export success of the AM economies.

Finally, the growth rates in both trade mark and product design competitiveness have been less impressive than the increase in patents and $\mathrm{R} \& \mathrm{D}$.

To put the export growth of the AM economies Table 2 displays the growth of real exports for the world decomposed into country groups over the period 1950-2010 following IMF's country classification. In this period world exports has increased 6.1 percent annually which about half of the growth experienced by the AM economies. The only country group that has experienced an export similar to the AM economies is the European developing countries which, predominantly, consists of the Eastern European countries.

Table 2: Real export volume

\begin{tabular}{ccccccccc}
\hline & World & $\begin{array}{c}\text { Industrial } \\
\text { Countries }\end{array}$ & $\begin{array}{c}\text { Developing } \\
\text { Countries }\end{array}$ & $\begin{array}{c}\text { Developing } \\
\text { Countries: } \\
\text { Africa }\end{array}$ & $\begin{array}{c}\text { Developing } \\
\text { Countries: } \\
\text { Asia }\end{array}$ & $\begin{array}{c}\text { Developing } \\
\text { Countries: } \\
\text { Europe }\end{array}$ & $\begin{array}{c}\text { Developing } \\
\text { Countries: } \\
\text { Middle East }\end{array}$ & $\begin{array}{c}\text { Developing } \\
\text { Countries: } \\
\text { Western } \\
\text { Hemisphere }\end{array}$ \\
\hline 1950 & 3.682 & 2.486 & 1.447 & 0.330 & 0.162 & 0.010 & 0.778 & 0.360 \\
1960 & 6.404 & 4.873 & 2.248 & 0.557 & 0.232 & 0.023 & 1.470 & 0.490 \\
1970 & 13.429 & 11.082 & 3.815 & 0.898 & 0.314 & 0.053 & 3.842 & 0.674 \\
1980 & 24.953 & 20.597 & 5.190 & 1.271 & 0.871 & 0.166 & 2.562 & 1.321 \\
1990 & 36.353 & 31.048 & 7.900 & 1.028 & 2.405 & 0.425 & 2.702 & 1.540 \\
2000 & 77.653 & 57.040 & 21.706 & 1.303 & 7.207 & 3.956 & 5.050 & 4.552 \\
2010 & 127.666 & 80.564 & 42.051 & 3.082 & 21.007 & 9.092 & 6.461 & 6.073 \\
\hline $\begin{array}{c}\text { Annual } \\
\text { average }\end{array}$ & $6.1 \%$ & $6.0 \%$ & $5.8 \%$ & $3.8 \%$ & $8.4 \%$ & $12.0 \%$ & $3.6 \%$ & $4.8 \%$ \\
growth rate & & & & & & & & \\
\hline
\end{tabular}

\subsection{Graphical analysis}

Figure 1 displays the growth in exports, trade-weighted income, price competitiveness, innovation stock, and innovation competitiveness for each country in in the group of AM economies. The knowledge stock is based on the first principal component stock of patents, $R \& D$, design and trademarks. The data are measured in logs and normalized to unity in the initial year 1953. The figure confirms the well-known fact that the AM economies have experienced spectacular export growth rates in the post-Korean War period. The annual growth rates even exceeded 25\% in the 1960s and 1970s for Japan, Korea, Singapore and Taiwan and, recently, for China. After experiencing marginally positive Hindu growth in the 1950s, 1960s and 1970s, India has since the 1991 reform faced growth rates in the vicinity of 15\%.

However, these export growth profiles do not accord well with the growth in trade-weighted income. The figure shows that the income growth rates among their trade partners has been much slower, 
and has averaged 4-5\% over the considered period - a growth rate that is not extraordinarily high taking into account that the income data are not measured in per capita terms. Furthermore, trade-weighted income among the AM economies, apart from Korea and Taiwan in the 1960s, has grown at almost the same rate for all the AM economies and, as such, does not explain their different timing of export growth spurts, although it cannot be ruled out that trade-weighted income has been influential for the trend in exports.

The growth in price competitiveness is consistent with the growth profile of Korea's exports during most of the period; however, it is much less consistent with the export growth pattern of other AM economies. Specifically, Korea improved its price competitive position in the 1960's and, at the same time, experienced a marked export boom, where a reduction in the price competitiveness measure indicates an improvement in competitiveness._The other countries have, on average over the entire period, only experienced a modest change in their price competitiveness. On average, the AM countries have not experienced much change in price competitiveness over this period. Thus, except for Korea, improvements in export price competitiveness could not have been an important driver for export growth in the AM economies.

The figures show that growth in the stock of knowledge and knowledge competitiveness appear to have been influential for exports in the AM economies. The stock of patent knowledge has grown at spectacular rates during most of the period and its growth rates, to a large extent, reflect the different timing of income and export growth spurts among the individual countries. The same applies to knowledge competitiveness, which has been increasing rapidly over the whole period and only in a few instances do the AM countries experience negative growth rates in knowledge competitiveness. Thus, knowledge stock and knowledge competitiveness may potentially have been important drivers behind the increases in exports among the AM economies. 
Figure 1: Growth rates of key variables (1953-2008)

(a) China

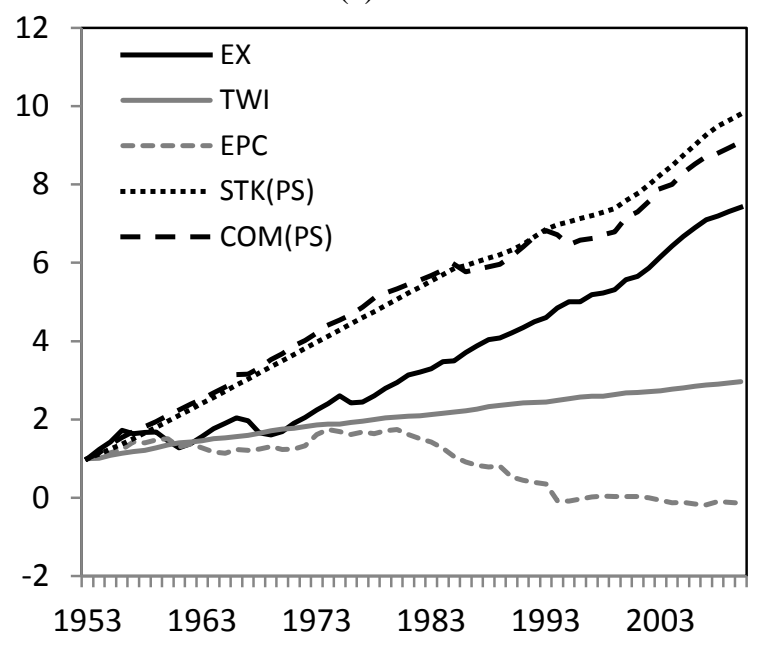

(c) Japan

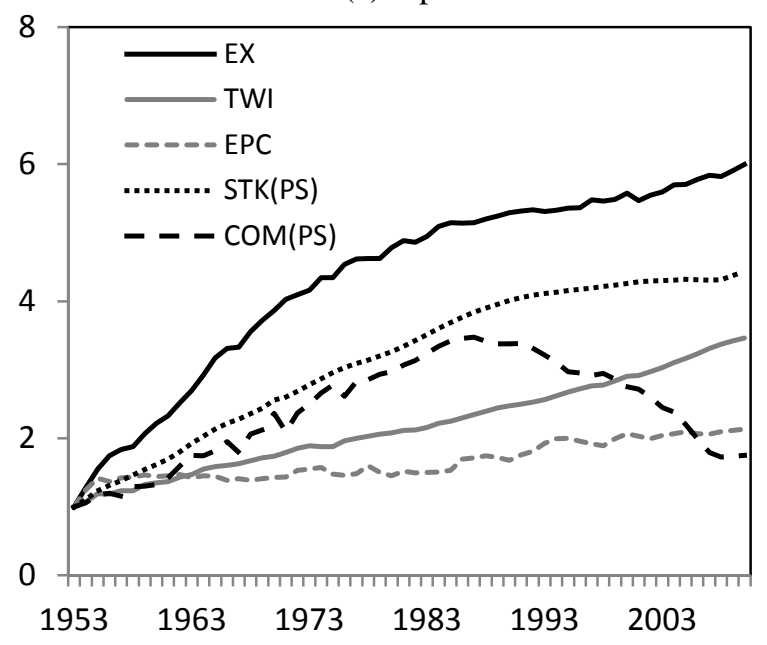

(e) Singapore

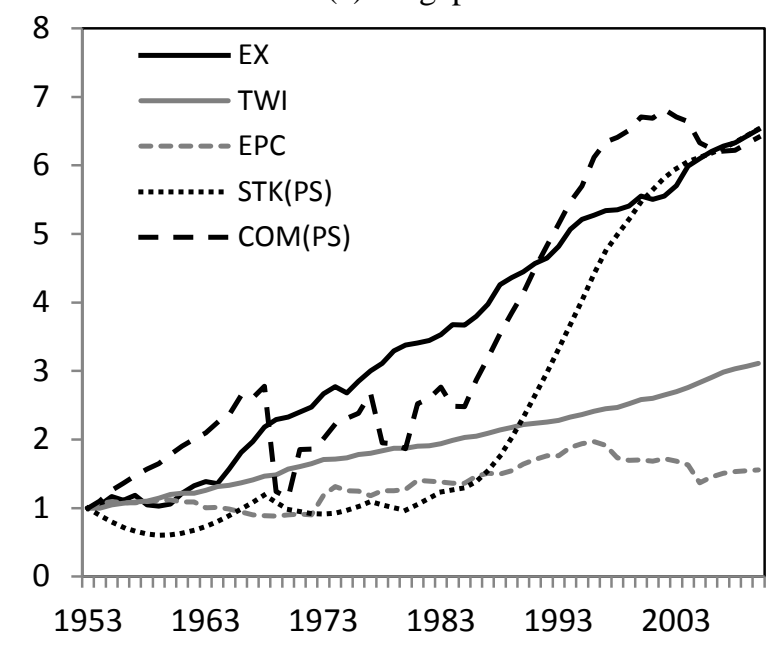

(b) India

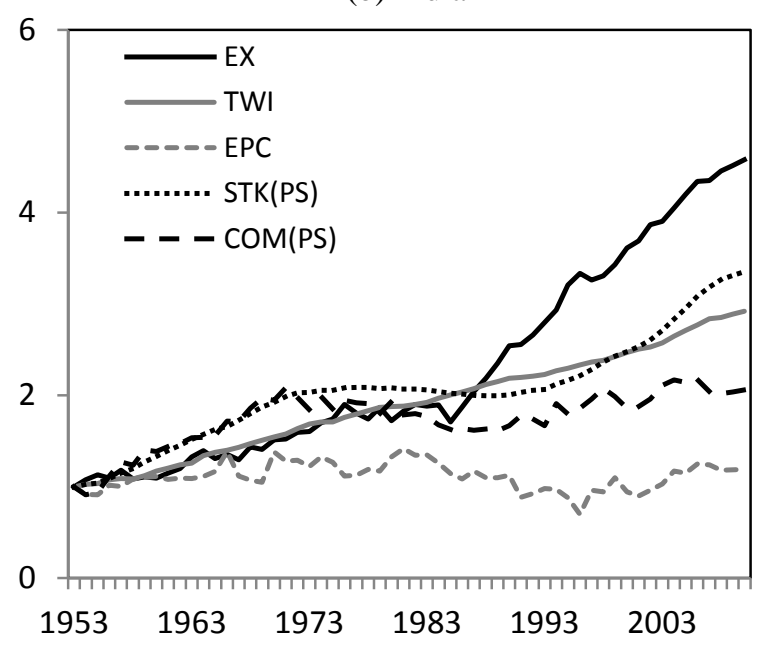

(d) South Korea

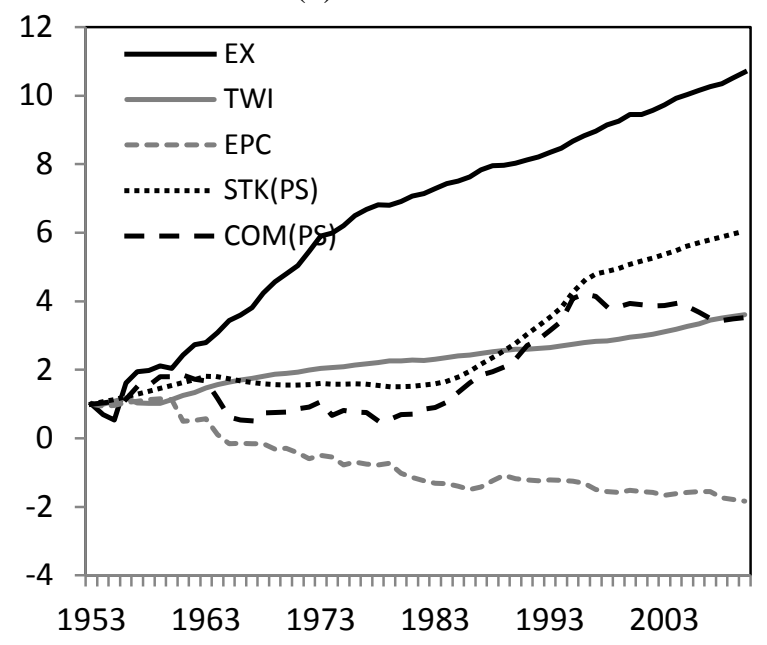

(f) Taiwan

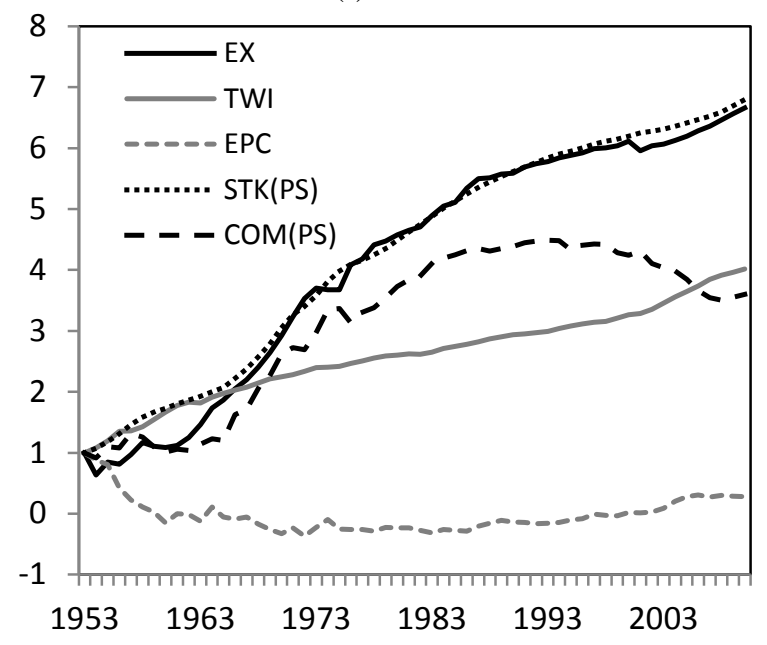

Notes: data are in logs and normalized to unity in 1953. See Data Appendix for the sources. 


\subsection{Baseline regression results}

The regression results for Eq. (4) are presented in Table 3. Considering first the OLS estimates in panel A, foreign income and export price competitiveness are significant determinants of export performance as predicted by our model and conventional models of exports. The coefficient of trade weighted income, however, is highly sensitive to the inclusion of innovation stock variables, indicating that the coefficient of trade weighted income is upward biased due to the omission of innovation variables in conventional export models. This can be seen by comparing the income elasticity estimates in Table 3 and the first column in Table 6, where innovation variables are excluded from the regression. The income elasticity is 2.7 when the innovation variables are excluded from the regressions (first column in Table 6); however, the income elasticity shrinks to 1.6 when innovations are measured by R\&D (first column in Table 3), which is probably the best measure of quality innovations as discussed below. An elasticity of 1.6 is probably much more realistic than one of 2.7 since the export-GDP ratio would otherwise increase to an unrealistically high value as income increases and, in the limit, exceeds its logical threshold.

Finally, the coefficients of innovation stock are statistically significant in all cases, regardless of which measure of innovation stock is included in the regression, reinforcing the importance of including innovative variables in the regressions. The innovation variables are also economically highly significant. The innovation stock has, on average, increased about nine percent annually, which it has contributed to an approximately three percent annual increase in exports based on the principal component estimates in the last column in panel A in Table 3.

Turning to the IV estimates consider first the first-round regressions are presented in Appendix Table A2. The coefficients of the focus variables in the innovation stock regression, i.e., cohort infant mortality and temperature, are mostly statistically highly significant and of the right sign. Cohort infant mortality is also economically highly significant and has been the main factor behind the trend increase in the innovative stock (the simulations are not shown). For the price equations associated with estimates of Eq. (4) the coefficients of union membership and real food prices are all positive and, statistically, highly significant.

Various test statistics for instrument adequacy reported in panel C in Table 3. The tests do not give evidence against the instruments. The first-stage $R$-squared values and the $F$-test of excluded instruments for both the innovation and export price competitiveness are both favorable to our identification strategy. The F-values are well above the rule-of-thumb critical value of 10 except in one case where it is 9.4. Note that the $F$-tests and $R$-squared tests are for competitiveness the same in all columns because the dependent variable is the same. The Kleibergen-Paap test rejects the hypothesis of under-identification in almost all cases, suggesting that the excluded instruments are correlated with the 
endogenous regressors and, therefore, are relevant instruments. In all, but one case, the Hansen $J$-test statistics indicate the null hypothesis of that the instruments are uncorrelated with the error term cannot be rejected, suggesting that the excluded instruments are valid and are correctly excluded from the structural equation. Finally, the Kleibergen-Paap tests of weak identification suggest that the excluded instruments are correlated with the endogenous regressors, thus rejecting the null hypothesis that the instruments are weak. Overall, these results give strong evidence in favor of the chosen instruments.

Panel B in Table 3 provides the IV estimates based on the fixed-effect estimator. The coefficients of foreign income are almost identical to the OLS estimates, which is not surprising since foreign income is un-instrumented in both regressions. The value of price competitiveness has, however, changed from an average value of -0.85 to an average value of -0.36 in moving from the OLS to the IV regressions. This result is consistent with the analysis of Madsen (1999) showing that the coefficient of price competitiveness is asymptotically biased towards - 1 in OLS regressions, as discussed above. If the absolute value of import elasticities are symmetrical to export price elasticities these results imply that the Marshal-Lerner condition that the sum of the absolute values of import and export price elasticities have to exceed one for a depreciation to improve the trade balance, is not satisfied.

Table 3: Innovation stock and export performance

\begin{tabular}{|c|c|c|c|c|c|}
\hline & (1) & $(2)$ & (3) & (4) & (5) \\
\hline $\begin{array}{l}\text { Dep. Var. = Total export volume } \\
(E X)\end{array}$ & \multicolumn{5}{|c|}{ Panel A: Pooled OLS estimates } \\
\hline Trade weighted income (TWI) & $\begin{array}{l}1.598^{* * *} \\
(0.131)\end{array}$ & $\begin{array}{l}2.080^{* * *} \\
(0.094)\end{array}$ & $\begin{array}{l}2.016^{* * *} \\
(0.121)\end{array}$ & $\begin{array}{l}2.488^{* * *} \\
(0.064)\end{array}$ & $\begin{array}{l}2.009^{* * *} \\
(0.133)\end{array}$ \\
\hline Export price competitiveness $\left(P^{e x}\right)$ & $\begin{array}{l}-1.078^{* * *} \\
(0.061)\end{array}$ & $\begin{array}{l}-0.897^{* * *} \\
(0.068)\end{array}$ & $\begin{array}{l}-0.653^{* * *} \\
(0.088)\end{array}$ & $\begin{array}{l}-0.850^{* * *} \\
(0.087)\end{array}$ & $\begin{array}{l}-0.748^{* * *} \\
(0.082)\end{array}$ \\
\hline $\mathrm{R} \& \mathrm{D}$ stock $\left(S T K^{R D}\right)$ & $\begin{array}{l}0.386^{* * *} \\
(0.057)\end{array}$ & & & & \\
\hline Patent stock $\left(S T K^{P S}\right)$ & & $\begin{array}{l}0.200^{* * *} \\
(0.033)\end{array}$ & & & \\
\hline Trade mark stock $\left(S T K^{T M}\right)$ & & & $\begin{array}{l}0.289^{* * *} \\
(0.064)\end{array}$ & & \\
\hline Product design stock $\left(S T K^{P D}\right)$ & & & & $\begin{array}{l}0.044^{*} \\
(0.026)\end{array}$ & \\
\hline $\begin{array}{l}1^{\text {st }} \text { principal component of innovation } \\
\text { stock }\left(S T K^{P C}\right)\end{array}$ & & & & & $\begin{array}{l}0.327^{* * *} \\
(0.081)\end{array}$ \\
\hline$R$-squared & 0.939 & 0.938 & 0.938 & 0.931 & 0.938 \\
\hline $\begin{array}{l}\text { Dep. Var. = Total export volume } \\
(E X)\end{array}$ & \multicolumn{5}{|c|}{ Panel B: Panel IV-FE estimates } \\
\hline Trade weighted income (TWI) & $\begin{array}{l}1.582^{* * *} \\
(0.510)\end{array}$ & $\begin{array}{l}2.182^{* * *} \\
(0.287)\end{array}$ & $\begin{array}{l}2.224^{* * *} \\
(0.203)\end{array}$ & $\begin{array}{l}2.519^{* * *} \\
(0.097)\end{array}$ & $\begin{array}{l}2.122^{* * *} \\
(0.230)\end{array}$ \\
\hline Export price competitiveness $\left(P^{e x}\right)$ & $\begin{array}{l}-0.517^{* * *} \\
(0.146)\end{array}$ & $\begin{array}{l}-0.555^{* * *} \\
(0.134)\end{array}$ & $\begin{array}{l}-0.201 \\
(0.157)\end{array}$ & $\begin{array}{l}-0.240 \\
(0.163)\end{array}$ & $\begin{array}{l}-0.290^{* *} \\
(0.143)\end{array}$ \\
\hline R\&D stock $\left(S T K^{R D}\right)$ & $0.455^{* *}$ & & & & \\
\hline
\end{tabular}


Patent stock $\left(S T K^{P S}\right)$

Trade mark stock $\left(S T K^{T M}\right)$

Product design stock $\left(S T K^{P D}\right)$

$1^{\text {st }}$ principal component of innovation stock $\left(S T K^{P C}\right)$

$R$-squared

No. of observations

No. of countries

(0.209)
$0.194^{*}$
(0.109)

$0.244^{* *}$

(0.098)

$0.123^{* *}$

(0.053)

\begin{tabular}{lllll} 
& & & $\begin{array}{l}0.330^{* * *} \\
(0.127)\end{array}$ \\
0.917 & 0.931 & 0.922 & 0.915 & 0.925 \\
348 & 348 & 348 & 348 & 348 \\
6 & 6 & 6 & 6 & 6 \\
\hline
\end{tabular}

Panel C: Diagnostic tests for panel IV-FE estimates

$\begin{array}{llllll}1^{\text {st }} \text {-stage } R \text {-squared (STK equation) } & 0.910 & 0.788 & 0.843 & 0.448 & 0.844 \\ F \text {-test of excluded IV (STK equation) } & 9.400 & 14.820 & 29.840 & 18.030 & 20.280 \\ 1^{\text {st }} \text {-stage } R \text {-squared (EPC equation) } & 0.428 & 0.428 & 0.428 & 0.428 & 0.428 \\ \text { F-test of excluded IV ( } P^{\text {ex }} \text { equation) } & 29.230 & 29.230 & 29.230 & 29.230 & 29.230 \\ \text { Kleibergen-Paap test of under } & 30.089 & 22.918 & 52.448 & 43.276 & 55.261 \\ \text { identification } & {[0.000]} & {[0.000]} & {[0.000]} & {[0.000]} & {[0.000]} \\ \text { Hansen } J \text {-test (over identification test } & 3.889 & 7.962 & 4.144 & 3.782 & 3.761 \\ \text { of all instruments) } & {[0.143]} & {[0.019]} & {[0.126]} & {[0.151]} & {[0.153]} \\ \text { Kleibergen-Paap test of weak } & 8.748 & 7.332 & 29.338 & 20.500 & 22.074 \\ \text { identification } & \{7.560\} & \{7.560\} & \{7.560\} & \{7.560\} & \{7.560\}\end{array}$

Notes: The Kleibergen-Paap under-identification test is the robust version of the Anderson canonical correlations test. Its null hypothesis is that the equation is identified, meaning that the excluded instruments are irrelevant. The Hansen $J$-test is a test of over-identifying restrictions with the null hypothesis that the instruments are valid. The Kleibergen-Paap test of weak identification is the robust version of the Cragg-Donald test and tests whether the excluded instruments are correlated with the endogenous regressors. The null hypothesis is that the instruments are weak. Robust standard errors are reported in the round parentheses. Figures in [ ] report $p$-values whereas those in \{ \} show the Stock-Yogo critical value for the Kleibergen-Paap test of weak identification using the $10 \%$ maximal IV relative bias as the decision rule. ${ }^{*}, * *$ and $* * *$ indicate significance at the $10 \%, 5 \%$ and $1 \%$ levels, respectively.

The coefficients of the innovation stock variables remain significant and of the expected sign in all the IV regressions, reinforcing the OLS results that innovation is important for export performance. The magnitude of the coefficients has, on average, not changed much from going from the OLS to the IV fixed effect estimator. This implies that innovations are genuinely promoting exports and that the OLS estimates have not been driven by a third factors that has simultaneously promoted exports and innovations such as market reforms and changes in property right institutions, for example. The coefficient of R\&D knowledge, which is our preferred measure of innovation stock, is 0.46 . This implies that the average 10.3 percent increase in $R \& D$ stock has contributed to a 4.7 percent annual increase in exports in the AM countries, which is a large contribution to the average 11.1 percent increase in exports. Trade-weighted income, on the other hand, has contributed 6.7\% to export growth. However, it is likely that trade-weighted income in the regressions has captured the contribution of foreign market access 
along with the improvement of supply conditions, as argued by Redding and Venables (2003), or by other forces as discussed below.

Table 4: Innovation competitiveness and export performance
(1)
(2)
(3)
(4)
(5)

Dep. Var. $=$ Total export volume (EX)

\begin{tabular}{|c|c|c|c|c|c|}
\hline Trade weighted income (TWI) & $\begin{array}{l}2.279^{* * *} \\
(0.081)\end{array}$ & $\begin{array}{l}2.156^{* * *} \\
(0.060)\end{array}$ & $\begin{array}{l}2.243^{* * *} \\
(0.047)\end{array}$ & $\begin{array}{l}2.543^{* * *} \\
(0.045)\end{array}$ & $\begin{array}{l}2.028^{* * *} \\
(0.049)\end{array}$ \\
\hline Export price competitiveness $\left(P^{e x}\right)$ & $\begin{array}{l}-0.948^{* * *} \\
(0.064)\end{array}$ & $\begin{array}{l}-0.888^{* * *} \\
(0.064)\end{array}$ & $\begin{array}{l}-0.254^{* * *} \\
(0.075)\end{array}$ & $\begin{array}{l}-0.444^{* * *} \\
(0.087)\end{array}$ & $\begin{array}{l}-0.438^{* * *} \\
(0.077)\end{array}$ \\
\hline $\begin{array}{l}\text { R\&D stock competitiveness } \\
\left(C O M^{R D}\right)\end{array}$ & $\begin{array}{l}0.204^{* * *} \\
(0.048)\end{array}$ & & & & \\
\hline $\begin{array}{l}\text { Patent stock competitiveness } \\
\left(C O M^{P S}\right)\end{array}$ & & $\begin{array}{l}0.239^{* * *} \\
(0.028)\end{array}$ & & & \\
\hline $\begin{array}{l}\text { Trade mark stock competitiveness } \\
\left(C O M^{T M}\right)\end{array}$ & & & $\begin{array}{l}0.671^{* * *} \\
(0.036)\end{array}$ & & \\
\hline $\begin{array}{l}\text { Product design stock competitiveness } \\
\left(C O M^{P D}\right)\end{array}$ & & & & $\begin{array}{l}0.290^{* * *} \\
(0.031)\end{array}$ & \\
\hline $\begin{array}{l}1^{\text {st }} \text { principal component of innovation } \\
\text { competitiveness }\left(C O M^{P C}\right)\end{array}$ & & & & & $\begin{array}{l}0.419^{* * *} \\
(0.024)\end{array}$ \\
\hline$R$-squared & 0.936 & 0.946 & 0.956 & 0.946 & 0.959 \\
\hline $\begin{array}{l}\text { Dep. Var. = Total export volume } \\
(E X)\end{array}$ & Panel B: & IV-FE es & & & \\
\hline Trade weighted income (TWI) & $\begin{array}{l}2.234^{* * *} \\
(0.262)\end{array}$ & $\begin{array}{l}2.165^{* * *} \\
(0.134)\end{array}$ & $\begin{array}{l}2.446^{* * *} \\
(0.106)\end{array}$ & $\begin{array}{l}2.621^{* * *} \\
(0.059)\end{array}$ & $\begin{array}{l}2.263^{* * *} \\
(0.116)\end{array}$ \\
\hline Export price competitiveness $\left(P^{e x}\right)$ & $\begin{array}{l}-0.339^{*} \\
(0.199)\end{array}$ & $\begin{array}{l}-0.598^{* * *} \\
(0.135)\end{array}$ & $\begin{array}{l}-0.105 \\
(0.182)\end{array}$ & $\begin{array}{l}-0.198 \\
(0.144)\end{array}$ & $\begin{array}{l}-0.215 \\
(0.152)\end{array}$ \\
\hline $\begin{array}{l}\text { R\&D stock competitiveness } \\
\left(C O M^{R D}\right)\end{array}$ & $\begin{array}{l}0.366^{*} \\
(0.208)\end{array}$ & & & & \\
\hline $\begin{array}{l}\text { Patent stock competitiveness } \\
\left(C O M^{P S}\right)\end{array}$ & & $\begin{array}{l}0.279^{* * *} \\
(0.070)\end{array}$ & & & \\
\hline $\begin{array}{l}\text { Trade mark stock competitiveness } \\
\left(C O M^{T M}\right)\end{array}$ & & & $\begin{array}{l}0.435^{* * *} \\
(0.150)\end{array}$ & & \\
\hline $\begin{array}{l}\text { Product design stock competitiveness } \\
\left(C O M^{P D}\right)\end{array}$ & & & & $\begin{array}{l}0.255^{* * *} \\
(0.071)\end{array}$ & \\
\hline $\begin{array}{l}1^{\text {st }} \text { principal component of innovation } \\
\text { competitiveness }\left(C O M^{P C}\right)\end{array}$ & & & & & $\begin{array}{l}0.302^{* * *} \\
(0.073)\end{array}$ \\
\hline$R$-squared & 0.908 & 0.940 & 0.943 & 0.940 & 0.949 \\
\hline No. of observations & 348 & 348 & 348 & 348 & 348 \\
\hline No. of countries & 6 & 6 & 6 & 6 & 6 \\
\hline
\end{tabular}

Panel C: Diagnostic tests for panel IV-FE estimates

\begin{tabular}{|c|c|c|c|c|c|}
\hline $1^{\text {st }}$-stage $R$-squared (COM equation) & 0.909 & 0.779 & 0.835 & 0.397 & 0.835 \\
\hline $\begin{array}{l}\text { F-test of excluded IV (COM } \\
\text { equation) }\end{array}$ & 8.230 & 22.240 & 15.220 & 15.690 & 18.920 \\
\hline $1^{\text {st }}$-stage $R$-squared ( $P^{e x}$ equation) & 0.385 & 0.385 & 0.385 & 0.385 & 0.385 \\
\hline F-test of excluded IV (EPC equation) & 25.830 & 25.830 & 25.830 & 25.830 & 25.830 \\
\hline Kleibergen-Paap test of under & 22.948 & 26.818 & 49.585 & 43.516 & 38.821 \\
\hline identification & {$[0.000]$} & {$[0.000]$} & [0.000] & [0.000] & [0.000] \\
\hline Hansen J-test (over identification test & 9.338 & 1.131 & 4.671 & 5.825 & 1.266 \\
\hline
\end{tabular}


of all instruments)

Kleibergen-Paap test of weak

identification
[0.010]

6.284

$\{7.560\}$
[0.568]

10.697

$\{7.560\}$
[0.097]

16.930

$\{7.560\}$
[0.054]

16.761

$\{7.560\}$
[0.531]

19.639

$\{7.560\}$

Notes: The Kleibergen-Paap under-identification test is the robust version of the Anderson canonical correlations test. Its null hypothesis is that the equation is identified, meaning that the excluded instruments are irrelevant. The Hansen $J$-test is a test of over-identifying restrictions with the null hypothesis that the instruments are valid. The Kleibergen-Paap test of weak identification tests whether the excluded instruments are correlated with the endogenous regressors. The null hypothesis is that the instruments are weak. Robust standard errors are reported in the round parentheses. Figures in [ ] report the p-values whereas those in \{\} report the Stock-Yogo critical value for the Kleibergen-Paap test of weak identification using the $10 \%$ maximal IV relative bias as the decision rule. ${ }^{*}, * *$ and $* * *$ indicate significance at the $10 \%, 5 \%$ and $1 \%$ levels, respectively.

The results of estimating Eq. (5) are presented in Table 4. The tests for instrument adequacy do not, in almost all cases, give evidence against the instruments. The first-stage $R$-squared values and the $F$ test of excluded instruments are both good, the Kleibergen-Paap test of under identification rejects the hypothesis of under-identification in almost all cases and Hansen's $J$-test statistics indicate the null hypothesis of that the instruments are uncorrelated with the error term cannot be rejected. Furthermore, cohort infant mortality and temperature, are mostly highly significant and of the right sign for innovation competitiveness (Appendix Table A3). Cohort infant mortality is also economically highly significant and has been the main factor behind the trend increase in the innovative competitiveness in the AM economies. For the price equations associated with estimates of Eq. (5) the coefficients of union membership and real food prices are all positive and statistical significant. Simulations of the models show that real food prices and union membership rates have been about equally important in explaining the path in price competitiveness.

The coefficients of trade weighted income are higher than those in Table 3, which is likely to reflect that innovation stock is no longer included in the regression as a scale variable and, therefore, that income has taken over as the principal scale variable. The absolute value of price competitiveness is, again, reduced substantially in going from the OLS to the IV estimates. The point estimate is, on average, 0.29 , which is even lower than the average estimate from Table 3, giving further evidence against depreciations as means of improving trade balances. Finally, the coefficients of innovation competitiveness are all statistically significant and of the expected sign. Importantly, the coefficients of trademarks and product design competitiveness are larger than those of R\&D and patent competitiveness; a result that is almost opposite to the results for innovation stock. These results suggest that firms in the AM economies compete more on design than the quality of products, while the opposite holds true for product innovations. 


\subsection{System approach}

The estimators used to produce the results in Tables 3 and 4 have not explicitly dealt with shortrun dynamics. The panel vector error-correction model (VECM) and the between-dimension fullymodified OLS (FM-OLS) estimators are used in this sub-section, implying that instruments are not used. The VECM is a system approach that not only allows for short-run dynamics, but also corrects for endogeneity bias by treating all underlying variables as endogenous while the FM-OLS estimator applies semi-parametric correction to the OLS estimator to eliminate the endogeneity bias. The panel unit root and cointegration tests discussed in the appendix (Section B) suggest that all variables contain unit roots and the models specified in Eqs. (4) and (5) are cointegrated, suggesting using the VECM and the FMOLS approaches are appropriate supplements to the IV regressions.

Table 5: Panel vector error-correction model (VECM) and fully-modified OLS (FM-OLS) estimates

\begin{tabular}{|c|c|c|c|c|c|c|c|c|c|c|}
\hline & (1) & (2) & (3) & (4) & (5) & (6) & (7) & (8) & (9) & (10) \\
\hline & VECM & VECM & VECM & VECM & VECM & $\begin{array}{l}\text { FM- } \\
\text { OLS }\end{array}$ & $\begin{array}{l}\text { FM- } \\
\text { OLS }\end{array}$ & $\begin{array}{l}\text { FM- } \\
\text { OLS }\end{array}$ & $\begin{array}{l}\text { FM- } \\
\text { OLS }\end{array}$ & $\begin{array}{l}\text { FM- } \\
\text { OLS }\end{array}$ \\
\hline $\begin{array}{l}\text { Dep. Var. }=\text { Total export } \\
\text { volume }(E X)\end{array}$ & \multicolumn{10}{|c|}{ Panel A: Export performance and innovation } \\
\hline $\begin{array}{l}\text { Trade weighted income } \\
(T W I)\end{array}$ & $\begin{array}{l}1.97^{* * *} \\
(0.22)\end{array}$ & $\begin{array}{l}2.02^{* * * *} \\
(0.16)\end{array}$ & $\begin{array}{l}1.77^{* * *} \\
(0.20)\end{array}$ & $\begin{array}{l}2.10^{* * *} \\
(0.18)\end{array}$ & $\begin{array}{l}1.94^{\text {*** }} \\
(0.17)\end{array}$ & $\begin{array}{l}1.46^{* * *} \\
(0.18)\end{array}$ & $\begin{array}{l}0.93^{* * *} \\
(0.11)\end{array}$ & $\begin{array}{l}0.56^{* * *} \\
(0.13)\end{array}$ & $\begin{array}{l}1.85^{* * *} \\
(0.06)\end{array}$ & $\begin{array}{l}0.54^{* * *} \\
(0.08)\end{array}$ \\
\hline $\begin{array}{l}\text { Export price } \\
\text { competitiveness }\left(P^{e x}\right)\end{array}$ & $\begin{array}{c}-0.83^{* * *} \\
(0.20)\end{array}$ & $\begin{array}{l}-0.71^{* * *} \\
(0.17)\end{array}$ & $\begin{array}{l}-0.49^{* *} \\
(0.20)\end{array}$ & $\begin{array}{c}0.08 \\
(0.24)\end{array}$ & $\begin{array}{c}-0.63^{* * * *} \\
(0.18)\end{array}$ & $\begin{array}{l}-0.39^{* * *} \\
(0.11)\end{array}$ & $\begin{array}{l}-0.50^{* * * *} \\
(0.08)\end{array}$ & $\begin{array}{l}-0.31^{* * *} \\
(0.09)\end{array}$ & $\begin{array}{l}-0.12 \\
(0.10)\end{array}$ & $\begin{array}{l}-0.56^{* * *} \\
(0.07)\end{array}$ \\
\hline R\&D stock $\left(S T K^{R D}\right)$ & $\begin{array}{l}0.16^{* * *} \\
(0.06)\end{array}$ & & & & & $\begin{array}{l}0.49^{* * * *} \\
(0.06)\end{array}$ & & & & \\
\hline Patent stock $\left(S T K^{P S}\right)$ & & $\begin{array}{l}0.11^{* * *} \\
(0.03)\end{array}$ & & & & & $\begin{array}{l}0.57^{* * *} \\
(0.04)\end{array}$ & & & \\
\hline $\begin{array}{l}\text { Trade mark stock } \\
\left(S T K^{T M}\right)\end{array}$ & & & $\begin{array}{l}0.34^{* * *} \\
(0.08)\end{array}$ & & & & & $\begin{array}{l}1.18^{* * *} \\
(0.07)\end{array}$ & & \\
\hline $\begin{array}{l}\text { Product design stock } \\
\left(S T K^{P D}\right)\end{array}$ & & & & $\begin{array}{l}0.30^{* * *} \\
(0.06)\end{array}$ & & & & & $\begin{array}{l}1.11^{* * *} \\
(0.07)\end{array}$ & \\
\hline $\begin{array}{l}1^{\text {st }} \text { principal component } \\
\text { of innovation stock } \\
\text { (STK }\end{array}$ & & & & & $\begin{array}{l}0.29^{* * *} \\
(0.064)\end{array}$ & & & & & $\begin{array}{l}1.48^{* * *} \\
(0.04)\end{array}$ \\
\hline Error-correction term & $\begin{array}{c}-0.06^{* * *} \\
(0.01)\end{array}$ & $\begin{array}{c}-0.06^{* * * *} \\
(0.01)\end{array}$ & $\begin{array}{l}-0.06^{* * * *} \\
(0.01)\end{array}$ & $\begin{array}{c}-0.05^{* * * *} \\
(0.01)\end{array}$ & $\begin{array}{c}-0.06^{* * *} \\
(0.01)\end{array}$ & - & - & - & - & - \\
\hline $\begin{array}{l}\text { Dep. Var. = Total export } \\
\text { volume }(E X)\end{array}$ & \multicolumn{10}{|c|}{ Panel B: Export performance and innovation competitiveness } \\
\hline Trade weighted income & $\begin{array}{l}1.73^{* * *} \\
(0.21)\end{array}$ & $\begin{array}{l}1.89^{* * *} \\
(0.15)\end{array}$ & $\begin{array}{l}2.16^{* * *} \\
(0.18)\end{array}$ & $\begin{array}{l}2.47^{* * *} \\
(0.19)\end{array}$ & $\begin{array}{l}1.95^{* * *} \\
(0.14)\end{array}$ & $\begin{array}{l}2.53^{* * *} \\
(16.11)\end{array}$ & $\begin{array}{l}1.66^{* * *} \\
(31.92)\end{array}$ & $\begin{array}{l}2.11^{* * *} \\
(36.91)\end{array}$ & $\begin{array}{l}2.58^{* * *} \\
(47.52)\end{array}$ & $\begin{array}{l}1.82^{* * *} \\
(36.40)\end{array}$ \\
\hline $\begin{array}{l}\text { Export price } \\
\text { competitiveness }\left(P^{e x}\right)\end{array}$ & $\begin{array}{c}-0.85^{* * *} \\
(0.19)\end{array}$ & $\begin{array}{c}-0.69^{* * *} \\
(0.15)\end{array}$ & $\begin{array}{l}-0.33 \\
(0.27)\end{array}$ & $\begin{array}{c}0.47 \\
(0.32)\end{array}$ & $\begin{array}{l}-0.19 \\
(0.17)\end{array}$ & $\begin{array}{l}-0.38^{* * * *} \\
(0.12)\end{array}$ & $\begin{array}{l}-0.21^{* * * *} \\
(0.07)\end{array}$ & $\begin{array}{l}0.01 \\
(0.20)\end{array}$ & $\begin{array}{l}0.14 \\
(0.1)\end{array}$ & $\begin{array}{l}-0.16^{* *} \\
(0.07)\end{array}$ \\
\hline $\begin{array}{l}\mathrm{R} \& \mathrm{D} \text { stock } \\
\text { competitiveness } \\
\left(C O M^{R D}\right)\end{array}$ & $\begin{array}{l}0.63^{* * *} \\
(0.12)\end{array}$ & & & & & $\begin{array}{l}0.18^{* *} \\
(0.09)\end{array}$ & & & & \\
\hline $\begin{array}{l}\text { Patent stock } \\
\text { competitiveness } \\
\left(C O M^{P S}\right)\end{array}$ & & $\begin{array}{c}0.37^{* * *} \\
(0.05)\end{array}$ & & & & & $\begin{array}{l}0.52^{* * *} \\
(0.02)\end{array}$ & & & \\
\hline $\begin{array}{l}\text { Trade mark stock } \\
\text { competitiveness } \\
\left(C O M^{T M}\right)\end{array}$ & & & $\begin{array}{c}0.340^{* *} \\
(0.16)\end{array}$ & & & & & $\begin{array}{l}0.97^{* * *} \\
(0.06)\end{array}$ & & \\
\hline
\end{tabular}


Product design stock

competitiveness

$\left(C O M^{P D}\right)$

$1^{\text {st }}$ principal component

of innovation

competitiveness

$\left(C O M^{P C}\right)$

Error-correction term
$0.33^{* * *}$

$0.43^{* * *}$

(0.06)
$0.66^{* * *}$

(0.04)

$\begin{array}{lllll}(0.009) & (0.010) & (0.009) & (0.007) & (0.010)\end{array}$

$\begin{array}{lllll}348 & 348 & 348 & 348 & 348\end{array}$

348

348

348

Notes: Intercepts but no time trends are included in the regressions. The optimal lag length is chosen based on SBC. Total export volume is normalized as the dependent variable. Country-specific fixed effects are included in the FM-OLS estimations. Figures in the round parentheses are standard errors. *, ** and *** indicate significance at the $10 \%, 5 \%$ and $1 \%$ levels, respectively.

The VECM and the FM-OLS results, which are presented in Table 5, are, to a large extent, consistent with the base-line IV results in Tables 3 and 4. However, they differ in three important respects from the base-line results. First, the absolute values of the coefficients of the competitiveness variables are low and even lower than the IV regressions, giving further evidence against devaluations/depreciations as tools for improving the trade balances. Second, the coefficients of innovations stock and innovation competitiveness are more significant determinants of export volumes than in the OLS-IV regressions, indicating that their elasticities may be underestimated in Tables 3 and 4. Third, the income elasticities are even lower in the FM-OLS regressions than in the other regressions; thus, reinforcing the discussion above that the income elasticity appears to beyond its logical size when innovation stock and innovation competitiveness are excluded from the regressions.

Finally, the error-correction terms are highly significant and of the right sign in the VECM regressions, suggesting that export volume is cointegrated with the regressors. The importance of this result is that the models are adequate models of exports and capture the most important driving forces for export.

\section{Further Analyses and robustness checks}

This sub-section conducts some sensitivity checks for the results. Given that the results, so far, are very robust to how innovation is measured the analysis henceforth considers only the first principal component measures to conserve space and all the results are based on the fixed-effect IV estimator.

\subsection{Conventional export model}

Consider first estimates of a conventional export equation in the first column in Table 6. The coefficient of foreign income is 2.7, which, as discussed above, is unrealistically high seen from the perspective that it cannot possibly represent a steady state solution since the export-income ratio would 
exceed its logical limit at some stage as productivity advances. As shown by Krugman (1989), high income elasticities are found for countries that are growing fast while they are low for slow growing countries. Since technological progress is entirely exogenous in standard neoclassical growth models we first consider a version of the model that omits the innovation variables.

\subsection{Competitiveness omitted}

The export price competitiveness is omitted from the regressions in column (2) since the model in Section 2 implies that export price competitiveness is not an essential determinant for export performance. The size and the significance of the coefficients of income, innovation stock and innovation competitiveness remain influential for exports, suggesting that the results are not sensitive to the exclusion of export price competitiveness from the regression model.

Table 6: Robustness checks

\begin{tabular}{|c|c|c|c|c|c|c|}
\hline & $(1)$ & $(2)$ & (3) & $(4)$ & $(5)$ & $(6)$ \\
\hline & $\begin{array}{c}\text { Exclude } \\
\text { innovation } \\
\text { variables }\end{array}$ & $\begin{array}{c}\text { Exclude } \\
\text { export } \\
\text { price }\end{array}$ & $\begin{array}{l}\text { Add trade } \\
\text { agreements } \\
\text { \& IPR }\end{array}$ & $\begin{array}{l}\text { Add trade } \\
\text { agreements } \\
\text { \& Polity } 2\end{array}$ & $\begin{array}{c}\text { Add trade } \\
\text { agreements, } \\
\text { IPR \& } \\
\text { Polity } 2 \\
\end{array}$ & $\begin{array}{c}\text { Add } \\
\text { CIF/FOB } \\
\text { ratio }\end{array}$ \\
\hline $\begin{array}{l}\text { Dep. Var. = Total export volume } \\
(E X)\end{array}$ & \multicolumn{6}{|c|}{ Panel A: Export performance and innovation } \\
\hline Trade weighted income (TWI) & $\begin{array}{l}2.68^{* * *} \\
(0.07)\end{array}$ & $\begin{array}{l}1.81^{* * *} \\
(0.33)\end{array}$ & $\begin{array}{l}1.86^{* * *} \\
(0.20)\end{array}$ & $\begin{array}{l}1.99^{* * *} \\
(0.21)\end{array}$ & $\begin{array}{l}1.85^{* * *} \\
(0.19)\end{array}$ & $\begin{array}{l}2.14^{* * *} \\
(0.23)\end{array}$ \\
\hline Export price comp. $\left(P^{e x}\right)$ & $\begin{array}{l}-0.39^{* *} \\
(0.18)\end{array}$ & & $\begin{array}{l}-0.33^{* *} \\
(0.14)\end{array}$ & $\begin{array}{l}-0.34^{* *} \\
(0.14)\end{array}$ & $\begin{array}{l}-0.35^{* *} \\
(0.14)\end{array}$ & $\begin{array}{l}-0.29^{* *} \\
(0.14)\end{array}$ \\
\hline $1^{\text {st }} \mathrm{PC}$ of innovation stock $\left(S T K^{P C}\right)$ & & $\begin{array}{l}0.55^{* * *} \\
(0.20)\end{array}$ & $\begin{array}{l}0.41^{* * *} \\
(0.12)\end{array}$ & $\begin{array}{l}0.38^{* * *} \\
(0.12)\end{array}$ & $\begin{array}{l}0.41^{* * *} \\
(0.12)\end{array}$ & $\begin{array}{l}0.31^{* * *} \\
(0.12)\end{array}$ \\
\hline Regional trade agreements & & & $\begin{array}{l}0.02^{*} \\
(0.01)\end{array}$ & $\begin{array}{l}0.02^{* * *} \\
(0.01)\end{array}$ & $\begin{array}{l}0.02^{*} \\
(0.01)\end{array}$ & \\
\hline IPR index & & & $\begin{array}{c}0.07 \\
(0.05)\end{array}$ & & $\begin{array}{l}-0.00 \\
(0.01)\end{array}$ & \\
\hline Polity2 & & & & $\begin{array}{c}0.00 \\
(0.01)\end{array}$ & $\begin{array}{c}0.07 \\
(0.05)\end{array}$ & \\
\hline $\mathrm{CIF} / \mathrm{FOB}$ ratio & & & & & & $\begin{array}{l}-0.37 \\
(1.17) \\
\end{array}$ \\
\hline R-squared & 0.91 & 0.91 & 0.93 & 0.93 & 0.93 & 0.93 \\
\hline $\begin{array}{l}\text { Dep. Var. = Total export volume } \\
(E X)\end{array}$ & \multicolumn{6}{|c|}{ Panel B: Export performance and innovation competitiveness } \\
\hline Trade weighted income (TWI) & $\begin{array}{l}2.68^{\text {*** }} \\
(0.07)\end{array}$ & $\begin{array}{l}2.13^{* * *} \\
(0.10)\end{array}$ & $\begin{array}{c}2.18^{* * *} \\
(0.08)\end{array}$ & $\begin{array}{l}2.10^{* * *} \\
(0.09)\end{array}$ & $\begin{array}{l}2.11^{* * *} \\
(0.10)\end{array}$ & $\begin{array}{l}2.25^{\text {*** }} \\
(0.13)\end{array}$ \\
\hline Export price comp. $\left(P^{e x}\right)$ & $\begin{array}{l}-0.39^{* *} \\
(0.18)\end{array}$ & & $\begin{array}{l}-0.23 \\
(0.15)\end{array}$ & $\begin{array}{c}-0.25 \\
(0.15)\end{array}$ & $\begin{array}{c}-0.23 \\
(0.15)\end{array}$ & $\begin{array}{c}-0.23 \\
(0.15)\end{array}$ \\
\hline $1^{\text {st }} \mathrm{PC}$ of innovation comp. $\left(C O M^{P C}\right)$ & & $\begin{array}{l}0.43^{* * *} \\
(0.08)\end{array}$ & $\begin{array}{l}0.34^{* * *} \\
(0.06)\end{array}$ & $\begin{array}{l}0.35^{* * *} \\
(0.05)\end{array}$ & $\begin{array}{l}0.34^{* * *} \\
(0.06)\end{array}$ & $\begin{array}{l}0.29^{* * *} \\
(0.07)\end{array}$ \\
\hline Regional trade agreements & & & $\begin{array}{c}0.01 \\
(0.01)\end{array}$ & $\begin{array}{c}0.01 \\
(0.01)\end{array}$ & $\begin{array}{c}0.01 \\
(0.01)\end{array}$ & \\
\hline IPR index & & & & $\begin{array}{l}-0.00 \\
(0.01)\end{array}$ & $\begin{array}{c}0.06 \\
(0.04)\end{array}$ & \\
\hline Polity2 & & & 0.00 & 0.06 & & \\
\hline
\end{tabular}




348

No. of obs.

Notes: An intercept is included in all estimations but not reported. Figures in the parentheses are robust standard errors. $*$, ** and $* * *$ indicate significance at the $10 \%, 5 \%$ and $1 \%$ levels, respectively. IPR $=$ intellectual property rights.

\subsection{Contracting institutions}

An emerging literature stresses the quality of institutions as important for export performance because transaction costs are inversely related to the quality of institutions. Levchenko (2007)) and Costinot (2009) argue that imperfect contract enforcement increase transaction costs and that reduced transaction costs increases the economic viability of the production of complex products; thus boosting exports. The more complex is the production of a good the larger it takes to learn how to perform the tasks and the larger are the gains from division of labor (Costinot, 2009). If the worker's contract is enforced, she performs her task in accordance with the terms of her contract; otherwise she does not perform at all. Related to this, contract enforcement also matters for exports because it allows agents to overcome frictions that arise when two parties with competing interests enter a production relationship (Levchenko, 2007). Thus, as the contractual arrangements improve the complex sector gains comparative advantage in exports vis-à-vis its competitors (Levchenko, 2007).

An index of the quality of contracting institutions is included in the regressions to examine the transaction cost hypothesis. Contracting institutions are measured by an index of intellectual property rights (IPR). The index covers five dimensions: (1) patentability of various kinds of inventions; (2) membership in international patent arrangements; (3) provisions for loss protection; (4) enforcement mechanisms; and (5) duration of the patent term. Each dimension is assigned a value ranging from zero to one. The unweighted sum of these five values provides an indication of the overall level of IPR protection, with higher values reflecting greater levels of protection. We use IPR as a measure of the quality of contracting institutions because time-series data on contracting institutions are not available and because there is likely to be a high positive correlation between the quality of contracting institution and enforcement of property rights.

The results of adding IPR to the baseline regressions are show in columns (4) and (5) in Table 6. The coefficients of IPRs are insignificant at conventional significance levels in both cases and the results from the baseline regressions remain intact. The insignificance of coefficients of IPRs may be due to measurement errors since IPR does not measure contracting institutions directly. 


\subsection{Democracy}

Democracy may have positive effects on trade because democratic states are more likely to cooperate on trade policies. Mansfield et al. (2002) show, theoretically as well as empirically, that international cooperation in trade is influenced by the control that voters exert over political leaders. A key in their model is that trade agreements can enhance the utility of both heads of state and voters; thus prompting the leaders to engage in international cooperation on commercial issues and trade agreements to maintain their position in office.

Polity IV's index of democracy (polity 2) is included as an additional regressor to the baseline model and the results are shown in columns (3) and (4) in Table 6. Polity 2 is measured as the difference between the degree of democracy and autocracy, where a higher value reflects the presence of a more democratic regime. The coefficients of democracy are insignificant and the baseline results remain intact.

\subsection{Trade costs}

Bilateral trade arrangements and Costs of Insurance and Freight (CIF) are included in the regressions as measures of trade costs. Bilateral trade agreements are measured as the number of available trade agreements between an AM economy and other economies in the region in any particular year. A bilateral trade agreement takes the value of one at the year at which the agreement has been sealed and remains one as long as the agreement is in force and zero otherwise. The number of bilateral trade agreements between country $i$ (home country) and country $j$ (any export partner) is added together. A free trade agreement is likely to enhance exports because of a public commitment by leaders to a less protectionist policy than otherwise. Adding bilateral trade agreements to our baseline regressions (columns (3)-(5) in Table 6) do not alter the baseline regression results. The coefficients of trade agreements are positive and statistically significant at the 10 percentage levels in half of the cases; otherwise insignificant.

Economically, trade agreements are not that influential for trade; 50 trade agreements are required to lift exports by one percent.

Insurance and freight costs are included in the regression in the last column in Table 6. Trade costs are proxied by the CIF-FOB ratio, where FOB is Free on Board value, which is the value at the exporter's border while the importer declares the CIF mirror value. The baseline regression results remain intact while the coefficient of the CIF-FOB ratio is insignificant. Its significance may be due to small identifying variations in the CIF-FOB ratio and that the CIF-FOB ratio has only been a small fraction of the total costs of the final good. Furthermore, exporters may absorb changes in CIF-FOB trade costs in their mark-ups, at least in the short run. 


\subsection{Restricted samples}

Although the AM economies share a marked success in productivity and export growth in the post-WWII period there are significant differences between the countries in the group and this difference may influence the response of exports to innovations. There is evidence of very high levels of incremental innovation in China and India and the emergence of Asian value chains, suggests that that the relationship between of innovation and trade may have shifted in important ways over time due to falling direct ad indirect trade costs. The recent literature on Asian trade networks shows that in India and China the process of export led growth has differed in important way from the earlier AM economies. First it has been widely observed that China’s export processing trade has very low value added so that China’s comparative advantage is in labor intensive assembly rather than the final goods it actually exports, with the classic example being the Ipad (Linden et al., 2009). Second, Puga and Trefler (2010) argue that there has been a rapid increase in incremental innovation - that is innovations leading to new intermediate goods that are traded - in a small number of low wage countries including, in particular, India and China. ${ }^{5}$ Similar evidence is given by Hanson (2012) and Baldwin and Lopez-Gonzalez (2013). Thus Asian value chains may have facilitated specialization in intermediate stages of production which has, in turn, facilitated the production of new intermediate goods.

The figures above show that China's innovation boom does not coincide with its export boom, which started earlier and that the time at which the countries open up to international trade differ between India and China and the other AM economies. Korea and Japan, for example, opened up to trade much earlier than India and China. Consequently, confounding factors may have plagued the regression results above and it would be of valuable to decompose the AM economies into country groups. To that end Table 7 reports the results for the following three country groups: 1) China and India; 2) Singapore, Taiwan, Japan and Korea; and 3) Korea and Japan.

Table 7: Restricted samples

\begin{tabular}{lcccccc}
\hline \multirow{2}{*}{$\begin{array}{l}\text { Dep. Var. = Total export volume } \\
(E X)\end{array}$} & $(1)$ & $(2)$ & $(3)$ & $(4)$ & $(5)$ & $(6)$ \\
\cline { 2 - 6 } & $\begin{array}{c}\text { China \& } \\
\text { India }\end{array}$ & $\begin{array}{c}\text { Asia 4 } \\
\text { (excl. China } \\
\text { \& India) }\end{array}$ & $\begin{array}{c}\text { Japan \& } \\
\text { Korea }\end{array}$ & $\begin{array}{c}\text { China \& } \\
\text { India }\end{array}$ & $\begin{array}{c}\text { Asia 4 } \\
\text { (excl. China } \\
\text { \& India) }\end{array}$ & $\begin{array}{c}\text { Japan \& } \\
\text { Korea }\end{array}$ \\
\hline Trade weighted income $(T W I)$ & $0.858^{* * *}$ & 0.569 & $1.410^{* *}$ & $1.748^{* * *}$ & $1.620^{* * *}$ & $2.361^{* * *}$ \\
& $(0.150)$ & $(0.534)$ & $(0.568)$ & $(0.140)$ & $(0.422)$ & $(0.088)$ \\
Export price competitiveness $\left(P^{e x}\right)$ & $-0.716^{* * *}$ & $-0.477^{* * *}$ & $-0.555^{* *}$ & $-0.724^{*}$ & $-0.333^{*}$ & $-0.608^{* * *}$ \\
& $(0.191)$ & $(0.096)$ & $(0.242)$ & $(0.366)$ & $(0.172)$ & $(0.128)$ \\
$1^{\text {st }}$ principal component of & $0.361^{* * *}$ & $1.581^{* * *}$ & $1.287^{* * *}$ & & &
\end{tabular}

\footnotetext{
${ }^{5}$ For example they show that of all the medium technology new goods imported to the United States, from 2000-2002, 48\% of these were sourced from China and 10\% from India, making these two countries more important as a source of new goods than Japan.
} 
innovation stock $\left(S T K^{\mathrm{PC}}\right)$

$1^{\text {st }}$ principal component of

innovation competitiveness $\left(\mathrm{COM}^{\mathrm{PC}}\right)$

$R$-squared

No. of observations

No. of countries
$(0.093)$

$(0.319)$

0.979

116

116
$(0.475)$

\begin{tabular}{cccc} 
& $0.230^{*}$ & $0.848^{* * *}$ & $0.498^{* * *}$ \\
& $(0.132)$ & $(0.227)$ & $(0.076)$ \\
\hline 0.991 & 0.970 & 0.967 & 0.988 \\
116 & 116 & 232 & 116 \\
2 & 2 & 4 & 2 \\
\hline
\end{tabular}

Notes: An intercept is included in all estimations but not reported. Figures in the parentheses are robust standard errors. *, ** and $* * *$ indicate significance at the $10 \%, 5 \%$ and $1 \%$ levels, respectively.

The regression results differ in certain respects from the baseline regressions; however, they are more favorable to the hypothesis in this paper than the baseline regression results. First, the income elasticities are, on average, significantly lower in Table 7 than in the baseline regressions; thus, giving further support to the Krugman-thesis that income elasticities in many empirical studies tend to be biased upwards due to omission of innovation variables and due to pooling of the data across countries. Second, the price elasticities are, on average, slightly more negative than the baseline regressions but still not sufficiently negative to ensure that the Marshal-Lerner condition is met with confidence. Third, the coefficients of the innovation stock and innovation competitiveness are substantially higher than the coefficient of 0.30 in the baseline regressions in Table 3 and 4, except for China and India group where they are similar to the baseline regressions.

In summary, the coefficients of the innovation stock and competitiveness variables tend to be larger for the group consisting of Singapore, Taiwan, Japan and Korea, suggesting that innovation was more important for these countries than it, thus far, has been for China and India. On the face of it this result it appears to be evidence against the Puga and Trefler (2010) hypothesis, that there has been a rapid increase in incremental innovation in China and India. However, to consider this more carefully we need to consider the type of innovation being undertaken. Hence, we now turn to consider whether we can identify separate impacts from different types of innovations.

\subsection{Product variety versus product quality}

Thus far we have included the innovation variables separately in the regressions; however, these variables may complement each other. As noted above, patents and R\&D are more likely to result from improved product quality while new trademarks and product designs are more likely to reflect changes in product variety. To investigate this issue various combinations of the innovation variables are are considered in this section.

The regressions in Table 8 include different combinations of product variety (trademarks and product designs) and product quality (R\&D and patents) measures. The results are encouraging in that they show that the proxies for product variety and product quality mostly complement each other and, in 
most cases, are significant. Thus, for example, in Columns (1), (2) and (6) in Table 8 it can be seen that both the R\&D and the product variety variables are significant. The main difference between these results and those of the baseline regressions is that the coefficients of innovation stock and innovation competitiveness are less significant in Table 8; predominantly reflecting that the innovation variables are highly correlated.

Table 8: Product variety versus product quality

\begin{tabular}{|c|c|c|c|c|c|c|c|c|}
\hline $\begin{array}{l}\text { Dep. Var. }=\text { Total export } \\
\text { volume }(E X)\end{array}$ & (1) & $(2)$ & (3) & (4) & (5) & (6) & $(7)$ & (8) \\
\hline $\begin{array}{l}\text { Trade weighted income } \\
\text { (TWI) }\end{array}$ & $\begin{array}{l}1.439^{* * *} \\
(0.491)\end{array}$ & $\begin{array}{l}1.556^{* * *} \\
(0.484)\end{array}$ & $\begin{array}{l}2.533^{* * *} \\
(0.393)\end{array}$ & $\begin{array}{l}3.786^{* * *} \\
(1.031)\end{array}$ & $\begin{array}{l}2.185^{* * *} \\
(0.246)\end{array}$ & $\begin{array}{l}2.209^{* * *} \\
(0.190)\end{array}$ & $\begin{array}{l}2.019^{* * *} \\
(0.164)\end{array}$ & $\begin{array}{l}2.231^{* * *} \\
(0.217)\end{array}$ \\
\hline $\begin{array}{l}\text { Export price } \\
\text { competitiveness }\left(P^{e x}\right)\end{array}$ & $\begin{array}{l}-0.285 \\
(0.192)\end{array}$ & $\begin{array}{l}-0.308 \\
(0.192)\end{array}$ & $\begin{array}{l}0.214 \\
(0.457)\end{array}$ & $\begin{array}{l}0.579 \\
(0.720)\end{array}$ & $\begin{array}{l}-0.044 \\
(0.214)\end{array}$ & $\begin{array}{l}-0.049 \\
(0.193)\end{array}$ & $\begin{array}{l}-0.993^{* *} \\
(0.408)\end{array}$ & $\begin{array}{l}-0.513^{* * *} \\
(0.201)\end{array}$ \\
\hline R\&D stock $\left(S T K^{R D}\right)$ & $\begin{array}{l}0.359^{*} \\
(0.215)\end{array}$ & $\begin{array}{l}0.411^{* *} \\
(0.206)\end{array}$ & & & & & & \\
\hline Patent stock $\left(S T K^{P S}\right)$ & & & $\begin{array}{l}-0.306 \\
(0.339)\end{array}$ & $\begin{array}{l}-0.644 \\
(0.551)\end{array}$ & & & & \\
\hline Trade mark stock $\left(S T K^{T M}\right)$ & $\begin{array}{l}0.207^{*} \\
(0.111)\end{array}$ & & $\begin{array}{l}0.494 \\
(0.303)\end{array}$ & & & & & \\
\hline $\begin{array}{l}\text { Product design stock } \\
\left(S T K^{P D}\right)\end{array}$ & & $\begin{array}{l}0.114^{* *} \\
(0.058)\end{array}$ & & $\begin{array}{l}0.406 \\
(0.263)\end{array}$ & & & & \\
\hline $\begin{array}{l}\text { R\&D stock } \\
\text { competitiveness }\left(C O M^{R D}\right)\end{array}$ & & & & & $\begin{array}{l}0.249 \\
(0.187)\end{array}$ & $\begin{array}{l}0.362^{* *} \\
(0.157)\end{array}$ & & \\
\hline $\begin{array}{l}\text { Patent stock } \\
\text { competitiveness }\left(C O M^{P S}\right)\end{array}$ & & & & & & & $\begin{array}{l}0.461^{* * *} \\
(0.174)\end{array}$ & $\begin{array}{l}0.236^{*} \\
(0.128)\end{array}$ \\
\hline $\begin{array}{l}\text { Trade mark stock } \\
\text { competitiveness }\left(C O M^{T M}\right)\end{array}$ & & & & & $\begin{array}{l}0.387^{* *} \\
(0.154)\end{array}$ & & $\begin{array}{l}-0.366 \\
(0.367)\end{array}$ & \\
\hline $\begin{array}{l}\text { Product design stock } \\
\text { competitiveness }\left(C O M^{P D}\right)\end{array}$ & & & & & & $\begin{array}{l}0.254^{* * *} \\
(0.069)\end{array}$ & & $\begin{array}{l}0.060 \\
(0.125)\end{array}$ \\
\hline R-squared & 0.922 & 0.920 & 0.886 & 0.789 & 0.935 & 0.940 & 0.916 & 0.943 \\
\hline No. of observations & 348 & 348 & 348 & 348 & 348 & 348 & 348 & 348 \\
\hline
\end{tabular}

Notes: An intercept is included in all estimations but not reported. Figures in the parentheses are robust standard errors. *, ** and $* * *$ indicate significance at the $10 \%, 5 \%$ and $1 \%$ levels, respectively.

Next consider the Puga and Trefler (2010) hypothesis that the export growth in China and India has been driven more by innovations in production streams, rather than the traditional the product cycle argument of relocation of standardized technologies. Specifically they argue that a central feature behind the recent success of India and China has been the ability of these countries to deliver incremental innovation to foreign companies operating complex supply chains.

To further investigate the Puga-Trefler hypothesis regressions in Table 9 consider combinations of our alternative measures of innovation for China and India. The results show that end-product variety (designs and trademarks) are not significant determinants of exports at any conventional significance levels. However, as can be seen in columns (3), (4) (7), and (8) our measures of patent stock and patent 
competitiveness are significant for India and China. This suggests that there is indeed significant innovation in these two economies, which, as argued by Puga and Trefler (2010), is likely to be incremental process innovation. Thus the results give some evidence in favor of the Puga and Trefler (2010) hypothesis.

Table 9: Product variety versus product quality for China and India only

\begin{tabular}{|c|c|c|c|c|c|c|c|c|}
\hline $\begin{array}{l}\text { Dep. Var. = Total export } \\
\text { volume }(E X)\end{array}$ & (1) & $(2)$ & (3) & (4) & (5) & (6) & (7) & (8) \\
\hline $\begin{array}{l}\text { Trade weighted income } \\
(T W I)\end{array}$ & $\begin{array}{l}-1.549 \\
(2.237)\end{array}$ & $\begin{array}{l}-0.875 \\
(1.958)\end{array}$ & $\begin{array}{l}1.452^{* * *} \\
(0.336)\end{array}$ & $\begin{array}{l}0.550 \\
(0.405)\end{array}$ & $\begin{array}{l}2.193^{* * *} \\
(0.742)\end{array}$ & $\begin{array}{l}2.263^{* * *} \\
(0.777)\end{array}$ & $\begin{array}{l}-0.122 \\
(0.415)\end{array}$ & $\begin{array}{l}-0.191 \\
(0.469)\end{array}$ \\
\hline Export price & $-1.791^{* *}$ & $-1.786^{* *}$ & $-0.921^{* * *}$ & $-0.787^{* * *}$ & -0.811 & -0.548 & -0.232 & -0.286 \\
\hline competitiveness $\left(P^{e x}\right)$ & $(0.761)$ & $(0.754)$ & $(0.272)$ & $(0.248)$ & $(0.974)$ & $(2.923)$ & $(0.318)$ & $(0.942)$ \\
\hline R\&D stock $\left(S T K^{R D}\right)$ & $\begin{array}{l}0.849 \\
(0.694)\end{array}$ & $\begin{array}{l}0.777 \\
(0.667)\end{array}$ & & & & & & \\
\hline Patent stock $\left(S T K^{P S}\right)$ & & & $\begin{array}{l}0.529^{* *} \\
(0.247)\end{array}$ & $\begin{array}{l}0.596 * * \\
(0.258)\end{array}$ & & & & \\
\hline Trade mark stock $\left(S T K^{T M}\right)$ & $\begin{array}{l}0.261 \\
(0.197)\end{array}$ & & $\begin{array}{l}-0.456 \\
(0.313)\end{array}$ & & & & & \\
\hline $\begin{array}{l}\text { Product design stock } \\
\left(S T K^{P D}\right)\end{array}$ & & $\begin{array}{l}0.079 \\
(0.056)\end{array}$ & & $\begin{array}{l}-0.168 \\
(0.101)\end{array}$ & & & & \\
\hline $\begin{array}{l}\text { R\&D stock } \\
\text { competitiveness }\left(C O M^{R D}\right)\end{array}$ & & & & & $\begin{array}{l}-0.524 \\
(0.313)\end{array}$ & $\begin{array}{l}-0.470 \\
(0.344)\end{array}$ & & \\
\hline $\begin{array}{l}\text { Patent stock } \\
\text { competitiveness }\left(C O M^{P S}\right)\end{array}$ & & & & & & & $\begin{array}{l}0.323^{* * *} \\
(0.070)\end{array}$ & $\begin{array}{l}0.330^{* * *} \\
(0.081)\end{array}$ \\
\hline Trade mark stock & & & & & -0.136 & & 0.027 & \\
\hline competitiveness $\left(C O M^{T M}\right)$ & & & & & $(0.735)$ & & $(0.202)$ & \\
\hline $\begin{array}{l}\text { Product design stock } \\
\text { competitiveness }\left(C O M^{P D}\right)\end{array}$ & & & & & & $\begin{array}{l}0.022 \\
(0.690)\end{array}$ & & $\begin{array}{l}-0.006 \\
(0.225)\end{array}$ \\
\hline R-squared & 0.938 & 0.941 & 0.977 & 0.984 & 0.971 & 0.975 & 0.995 & 0.994 \\
\hline No. of observations & 116 & 116 & 116 & 116 & 116 & 116 & 116 & 116 \\
\hline
\end{tabular}

Notes: An intercept is included in all estimations but not reported. Figures in the parentheses are robust standard errors. *,** and $* * *$ indicate significance at the $10 \%, 5 \%$ and $1 \%$ levels, respectively.

\section{Concluding remarks}

The Asian miracle economies have experienced a marked increase in exports, and yet only a very few attempts, like Redding and Venables (2003), Jongwanich (2010), and Puga and Trefler (2010), have tried to explain the export success of these countries. This is a mystery in the light of the emphasis on openness as a key driver of growth in the development literature and the fact that export growth and trade openness have often been stressed as factors that have been influential for the success of the AM economies (see, for discussion, Lucas, 1993; Easterly, 1994; Rodrik, 1996, 1997; and Radelet et al., 2001). This paper has argued that the spectacular productivity and export growth rates of the AM countries have in common i that they are both predominantly driven by innovations. Based on a simple 
product variety endogenous growth model it is shown that export growth is an outcome of new product variety, which in turn is an outcome of R\&D in the intermediate goods producing sector. An R\&Dinduced increase in product variety affects exports directly as well as indirectly, through improved innovation stock and innovation competitiveness.

The innovation hypothesis was tested for the AM economies in the period 1953-2010 and external instruments were used to ensure that the results were not driven by unobserved heterogeneity. Unionization and real food prices were used as instruments for prices to construct price competitiveness while cohort infant mortality and temperature were used as instruments for innovation stock and innovation competitiveness. The regression results gave strong support to the innovation-driven export growth hypothesis. Innovation stock as well as innovation competitiveness were both significant determinants of exports along with trade weighted income, whereas price competitiveness was not a quantitatively important determinant of exports.

The IV regressions gave stronger support for the innovation hypothesis than the OLS estimates and showed that the price elasticities were significantly lower in the IV than the OLS estimates. This not only highlights the importance of using external instruments but also reinforces that policies that speed up innovations/imitations are much more effective in rectifying current account deficits than devaluations/depreciations. Finally, we found innovation stock and innovation competitiveness to have been significantly less influential for export growth for China and India than the other AM economies and that these countries' export boom has been predominantly based on incremental innovation/imitation (process innovation) and not fundamental innovation (product innovation) as predicted by the model of Puga and Trefler (2010).

\section{- Appendix}

\section{A. Time series panel estimators}

This section outlines the time series procedures used to estimate the cointegrating vectors specified in Eqs. (4) and (5) in the main text. First, for the ease of exposition, consider a simple bi-variate panel regression model:

$$
y_{i t}=\alpha+\beta_{i} x_{i t}+e_{i t}, \quad i=1, \ldots, N ; \quad t=1, \ldots, T
$$

The slope coefficient for a conventional panel OLS estimator is given as:

$$
\hat{\beta}_{i}^{O L S}=\left(\sum_{i=1}^{N} \sum_{t=1}^{T}\left(x_{i t}-\bar{x}_{i}\right)\left(y_{i t}-\bar{y}_{i}\right)\right) /\left(\sum_{i=1}^{N} \sum_{t=1}^{T}\left(x_{i t}-\bar{x}_{i}\right)^{2}\right)
$$

where $\bar{x}_{i}$ and $\bar{y}_{i}$ are the means of $x_{i}$ and $y_{i}$, respectively. 
Pedroni (2000) argues that the above OLS estimator is asymptotically biased. $\hat{\beta}_{i}^{\text {OLS }}$ would be unbiased only if $x$ is strictly exogenous and the dynamics are homogenous across the $i$ cross sections of the panel. To correct for endogeneity and serial correlation, Pedroni (2000) proposes the between-dimension (group-mean) fully-modified OLS (FM-OLS) panel estimator for estimating panel cointegration models. This is a single-equation approach that applies the Phillips and Hansen (1990) semi-parametric correction to the OLS estimator to eliminate bias due to endogeneity of the regressors. The heterogeneity present in the dynamics underlying $x$ and $y$ are also adjusted accordingly.

The approach is based on averaging the estimated slope coefficients for each country. Thus, compared to their within-dimension counterparts developed by Kao and Chiang (2000) and Mark and Sul (2003), the groupmean estimators are less restrictive in that they allow for heterogeneity where the slope coefficients can vary across countries in the panel. Moreover, Pedroni (2001) has also found that this estimator has relatively minor size distortions in finite samples compared to the within-dimension pooled estimators, and are thus more ideal for our estimation purpose.

Specficially, the expression of the between-dimension (group-mean) fully-modified OLS (FM-OLS) panel estimator is given as follows:

$$
\hat{\beta}_{i}^{F M-O L S}=\left(\sum_{i=1}^{N} \sum_{t=1}^{T}\left(x_{i t}-\bar{x}_{i}\right)\left(y_{i t}^{*}-T \hat{\gamma}_{i}\right)\right) / N\left(\sum_{i=1}^{N} \sum_{t=1}^{T}\left(x_{i t}-\bar{x}_{i}\right)^{2}\right)
$$

where $y_{i t}^{*}=\left(y_{i t}-\bar{y}_{i}\right)-\left(\frac{\widehat{\Omega}_{21 i}}{\widehat{\Omega}_{22 i}}\right) \Delta x_{i t}$ and $\hat{\gamma}_{i}=\widehat{\Gamma}_{21 i}+\widehat{\Omega}_{21 i}^{o}-\left(\frac{\widehat{\Omega}_{21 i}}{\widehat{\Omega}_{22 i}}\right)\left(\widehat{\Gamma}_{22 i}-\widehat{\Omega}_{22 i}^{o}\right) . \widehat{\Omega}$ and $\hat{\Gamma}$ are covariances and sums of autocovarainces obtained from the long-run covariance matrix in Eq. (A1). These estimators are used correct for the endogenous feedback of the regressor $x_{i t}$. In sum, the FM-OLS estimator provides an effective way to deal with nuisance parameters and achieves asymptotic efficiency by accounting for possible endogeneity of the regressors and serial correlation of the errors.

The panel vector error-correction model (VECM) is also employed for estimating cointegrating vectors. Unlike the above single-equation estimator which applies the semi-parametric procedure to correct for endogeneity bias, the VECM is a system approach that treats all underlying variables as endogenous. It therefore provides a more effective mechanism in dealing with endogeneity. Another main advantage of this approach is that differences in adjustment speeds and dynamics across the different individual countries are taken into account.

The panel VECM is built around the standard vector error-correction framework described in Johansen (1995) by stacking the different individual countries into a joint panel VECM. For exposition, consider a cointegrated vector autoregressive (VAR) model at order $p$ with a VECM presentation of the form:

$$
\Delta y_{i t}=\Phi_{i} d_{t}+\alpha_{i} \beta^{\prime} y_{i, t-1}+\sum_{j=1}^{p-1} \Gamma_{i, j} \Delta y_{i, t-j}+\varepsilon_{i t}, \quad i=1, \ldots, N ; \quad t=1, \ldots, T
$$

where $y_{i t}=\left(z_{1, i t}, z_{2, i t}, \ldots, z_{k, i t}\right), k$ is the number of endogenous variables in the system, $\Phi_{i}$ is a $k x k$ matrix of coefficients, $d_{t}$ is a vector of deterministic variables (such as constant, trend or dummy variables), $\alpha$ is the $k x r$ matrix of adjustment coefficient and $r$ is the number of cointegrated relationships, $\beta$ is the $k x r$ matrix of cointegrating vectors, $p$ is the optimal lag length, $\varepsilon_{i t}$ is an $k$-dimensional white noise error vector with $E\left(\varepsilon_{i t}\right)=0$ and positive definite covariance matrix $\sum_{i}=E\left(\varepsilon_{i t} \varepsilon_{i t}^{\prime}\right)$. Eq. (A4) is estimated using a maximum-likelihood estimator.

\section{B. Integration and cointegration analyses}

We employ two ADF-based panel unit root tests proposed by Maddala and Wu (1999) and Choi (2001) to assess the order of integration of the variables. The test results, which are not reported here to conserve space but are available upon request, show that all variables are not stationary in levels but become stationary after first differencing, i.e., they contain a unit root or I(1). The panel cointegration tests are performed using the ADF-based procedures of Pedroni (1999, 2004) and Kao (1999). Although Pedroni (1999, 2004) provides five other cointegration tests, these ADF-based tests are preferred since they have been found to perform best by the simulation studies of Wagner and Hlouskova (2010), whereas all other tests are found to have very low power in many circumstances. The results reported in Table A1 confirm that the underlying variables are cointegrated, indicating that there exists a long-run relationship between the variables that are included in the models, as 
assumed in Eqs. (4) and (5). In particular, the null hypothesis of no cointegration is rejected at conventional significance levels in nearly $80 \%$ of the case, thus indicating a rather strong long-run relationship between the variables included in the regressions.

Table A1: Cointegration tests

\begin{tabular}{|c|c|c|c|c|c|}
\hline \multirow[b]{2}{*}{$\begin{array}{l}\text { Dep. Var. = Export } \\
\text { volume }(E X)\end{array}$} & Model (1) & Model (2) & Model (3) & Model (4) & Model (5) \\
\hline & $\begin{array}{l}\text { Innovation = } \\
S T K^{R D}\end{array}$ & $\begin{array}{l}\text { Innovation = } \\
S_{S T}^{P S}\end{array}$ & $\begin{array}{l}\text { Innovation = } \\
S T K^{T M}\end{array}$ & $\begin{array}{l}\text { Innovation = } \\
S T K^{P D}\end{array}$ & $\begin{array}{l}\text { Innovation = } \\
S_{S T}^{P C}\end{array}$ \\
\hline & \multicolumn{5}{|c|}{ Model A: $E X=f(T W I, E P C, S T K)$ - Eq. (4) } \\
\hline $\begin{array}{l}\text { Panel ADF statistic } \\
(\text { ) }\end{array}$ & $\begin{array}{l}-0.856 \\
{[0.196]}\end{array}$ & $\begin{array}{l}-3.687^{* * *} \\
{[0.000]}\end{array}$ & $\begin{array}{l}-1.771^{* *} \\
{[0.038]}\end{array}$ & $\begin{array}{l}-0.595 \\
{[0.276]}\end{array}$ & $\begin{array}{l}-2.669^{* * *} \\
{[0.004]}\end{array}$ \\
\hline Group ADF statistic () & $\begin{array}{l}-0.743 \\
{[0.229]}\end{array}$ & $\begin{array}{l}-4.479^{* * *} \\
{[0.000]^{* * *}}\end{array}$ & $\begin{array}{l}-1.857^{* *} \\
{[0.032]}\end{array}$ & $\begin{array}{l}-0.077 \\
{[0.469]}\end{array}$ & $\begin{array}{l}-3.358^{* * *} \\
{[0.000]}\end{array}$ \\
\hline $\begin{array}{l}\text { ADF } t \text {-statistic } \\
\text { (Kao, 1999) }\end{array}$ & $\begin{array}{l}-4.238^{* * *} \\
{[0.000]}\end{array}$ & $\begin{array}{l}-3.644^{* * *} \\
{[0.000]}\end{array}$ & $\begin{array}{l}-3.571^{* * *} \\
{[0.000]}\end{array}$ & $\begin{array}{l}-2.977^{* * *} \\
{[0.002]}\end{array}$ & $\begin{array}{l}-3.778^{* * *} \\
{[0.000]}\end{array}$ \\
\hline \multirow[t]{2}{*}{$\begin{array}{l}\text { Dep. Var. = Export } \\
\text { volume }(E X)\end{array}$} & $\begin{array}{l}\text { Innovation } \\
\text { competitiveness } \\
=C O M^{R D}\end{array}$ & $\begin{array}{l}\text { Innovation } \\
\text { competitiveness } \\
=C O M^{P S}\end{array}$ & $\begin{array}{l}\text { Innovation } \\
\text { competitiveness } \\
=C O M^{T M} \\
\end{array}$ & $\begin{array}{l}\text { Innovation } \\
\text { competitiveness } \\
=C O M^{P D}\end{array}$ & $\begin{array}{l}\text { Innovation } \\
\text { competitiveness } \\
=C O M^{P C}\end{array}$ \\
\hline & \multicolumn{5}{|c|}{ Model B: $E X=f(T W I, E P C, C O M)$ - Eq. (5) } \\
\hline $\begin{array}{l}\text { Panel ADF statistic } \\
\text { () }\end{array}$ & $\begin{array}{l}-2.150^{* *} \\
{[0.016]}\end{array}$ & $\begin{array}{l}-0.377 \\
{[0.353]}\end{array}$ & $\begin{array}{l}-0.353 \\
{[0.351]}\end{array}$ & $\begin{array}{l}-1.595^{*} \\
{[0.055]}\end{array}$ & $\begin{array}{l}-2.470^{* * *} \\
{[0.007]}\end{array}$ \\
\hline Group ADF statistic () & $\begin{array}{l}-2.325^{* *} \\
{[0.010]}\end{array}$ & $\begin{array}{l}-2.779^{* * *} \\
{[0.003]}\end{array}$ & $\begin{array}{l}-0.144 \\
{[0.443]}\end{array}$ & $\begin{array}{l}-2.634^{* * *} \\
{[0.004]}\end{array}$ & $\begin{array}{l}-3.572^{* * *} \\
{[0.000]}\end{array}$ \\
\hline $\begin{array}{l}\text { ADF } t \text {-statistic } \\
(\text { Kao, 1999) }\end{array}$ & $\begin{array}{l}-3.585^{* * *} \\
{[0.000]}\end{array}$ & $\begin{array}{l}-4.456^{* * *} \\
{[0.000]}\end{array}$ & $\begin{array}{l}-3.563^{* * *} \\
{[0.000]}\end{array}$ & $\begin{array}{l}-3.255^{* * *} \\
{[0.001]}\end{array}$ & $\begin{array}{l}-5.259^{* * *} \\
{[0.000]}\end{array}$ \\
\hline
\end{tabular}

Notes: $\mathrm{RD}=\mathrm{R} \& \mathrm{D}$ stock, $\mathrm{PS}=$ patent stock, $\mathrm{TM}=$ trademark stock, $\mathrm{PD}=$ product design stock, $\mathrm{PC}=1^{\mathrm{st}}$ principal component of RD, PS, TM and PD. The null hypothesis is no cointegration. The optimal lag length is chosen using SBC. Intercepts but no time trends are included in the regressions. Figures in parentheses are $p$-values. $* * *, * *$ and $*$ denote significance at the $1 \%$, $5 \%$ and $10 \%$ levels, respectively.

\section{First-stage regressions for innovation stock and price competitiveness (Eq. (4))}

Table A2: First-stage regressions for innovation stock (Eq. (4))

\begin{tabular}{|c|c|c|c|c|c|}
\hline & Model (1) & Model (2) & Model (3) & Model (4) & Model (5) \\
\hline & $\begin{array}{c}\text { Innovation }= \\
S T K^{R D}\end{array}$ & $\begin{array}{c}\text { Innovation = } \\
\text { STK }\end{array}$ & $\begin{array}{c}\text { Innovation }= \\
S T K^{T M}\end{array}$ & $\begin{array}{c}\text { Innovation = } \\
S T K^{P D}\end{array}$ & $\begin{array}{c}\text { Innovation = } \\
\text { STK }^{P C}\end{array}$ \\
\hline $\begin{array}{c}\text { Dep. Var. = Innovation } \\
\text { stock }(S T K)\end{array}$ & \multicolumn{5}{|c|}{ Panel A: Innovation stock equation } \\
\hline Real food price index & $\begin{array}{l}-0.159^{* *} \\
(0.062)\end{array}$ & $\begin{array}{c}0.075 \\
(0.090)\end{array}$ & $\begin{array}{l}-0.120 \\
(0.080)\end{array}$ & $\begin{array}{l}0.785^{* * *} \\
(0.177)\end{array}$ & $\begin{array}{c}0.076 \\
(0.071)\end{array}$ \\
\hline Unionization & $\begin{array}{c}-0.299^{* * *} \\
(0.108)\end{array}$ & $\begin{array}{c}-0.813^{* * *} \\
(0.171)\end{array}$ & $\begin{array}{c}-1.090^{* * *} \\
(0.136)\end{array}$ & $\begin{array}{c}-0.886^{* * *} \\
(0.304)\end{array}$ & $\begin{array}{c}-0.676^{* * *} \\
(0.110)\end{array}$ \\
\hline Temperature & $\begin{array}{l}-2.664^{* * *} \\
(0.867)\end{array}$ & $\begin{array}{l}4.357^{* * *} \\
(1.316)\end{array}$ & $\begin{array}{l}4.714^{* * *} \\
(1.128)\end{array}$ & $\begin{array}{l}12.576^{* * *} \\
(2.686)\end{array}$ & $\begin{array}{l}3.714^{* * *} \\
(0.950)\end{array}$ \\
\hline Infant mortality & $\begin{array}{c}-0.797^{* * *} \\
(0.233)\end{array}$ & $\begin{array}{l}-1.523^{* * *} \\
(0.343)\end{array}$ & $\begin{array}{l}-0.107 \\
(0.304)\end{array}$ & $\begin{array}{l}2.836^{* * * *} \\
(0.706)\end{array}$ & $\begin{array}{c}0.032 \\
(0.270)\end{array}$ \\
\hline Constant & $\begin{array}{l}1.658^{* * *} \\
(0.247)\end{array}$ & $\begin{array}{l}0.598^{*} \\
(0.344)\end{array}$ & $\begin{array}{l}1.243^{* * *} \\
(0.291)\end{array}$ & $\begin{array}{l}2.885^{* * *} \\
(0.668)\end{array}$ & $\begin{array}{l}1.309^{* * *} \\
(0.259)\end{array}$ \\
\hline
\end{tabular}




\begin{tabular}{|c|c|c|c|c|c|}
\hline $\begin{array}{c}\text { Dep. Var. }=\text { price } \\
\text { competitiveness }\left(P^{e x}\right)\end{array}$ & \multicolumn{5}{|c|}{ Panel B: price competitiveness equation } \\
\hline Real food price index & $\begin{array}{l}0.263^{* * *} \\
(0.036)\end{array}$ & $\begin{array}{l}0.263^{* * *} \\
(0.036)\end{array}$ & $\begin{array}{l}0.263^{* * *} \\
(0.036)\end{array}$ & $\begin{array}{l}0.263^{* * *} \\
(0.036)\end{array}$ & $\begin{array}{l}0.263^{* * *} \\
(0.036)\end{array}$ \\
\hline Unionization & $\begin{array}{l}0.131^{*} \\
(0.068)\end{array}$ & $\begin{array}{l}0.131^{*} \\
(0.068)\end{array}$ & $\begin{array}{l}0.131^{*} \\
(0.068)\end{array}$ & $\begin{array}{l}0.131^{*} \\
(0.068)\end{array}$ & $\begin{array}{l}0.131^{*} \\
(0.068)\end{array}$ \\
\hline Temperature & $\begin{array}{l}-2.058^{* * *} \\
(0.694)\end{array}$ & $\begin{array}{l}-2.058^{* * *} \\
(0.694)\end{array}$ & $\begin{array}{l}-2.058^{* * *} \\
(0.694)\end{array}$ & $\begin{array}{l}-2.058^{* * *} \\
(0.694)\end{array}$ & $\begin{array}{c}-2.058^{* * *} \\
(0.694)\end{array}$ \\
\hline Infant mortality & $\begin{array}{c}-0.649^{* * *} \\
(0.152)\end{array}$ & $\begin{array}{c}-0.649^{* * *} \\
(0.152)\end{array}$ & $\begin{array}{l}-0.649^{* * *} \\
(0.152)\end{array}$ & $\begin{array}{c}-0.649^{* * *} \\
(0.152)\end{array}$ & $\begin{array}{c}-0.649^{* * *} \\
(0.152)\end{array}$ \\
\hline Constant & $\begin{array}{l}-0.614^{* * *} \\
(0.148)\end{array}$ & $\begin{array}{l}-0.614^{* * *} \\
(0.148)\end{array}$ & $\begin{array}{l}-0.614^{* * *} \\
(0.148)\end{array}$ & $\begin{array}{l}-0.614^{* * *} \\
(0.148)\end{array}$ & $\begin{array}{l}-0.614^{* * *} \\
(0.148)\end{array}$ \\
\hline
\end{tabular}

Notes: all variables are measured in logs. Real food price index is the average price of food divided by consumer prices; unionization is the ratio of union membership to total employment; temperature is the average temperature during the year; and infant mortality is the number of infant deaths per 1000 during the first year of life; RD = R\&D stock; PS = patent stock; TM = trademark stock; PD = product designs stock; and PC = the first principal component of these four measures. Estimates for the price competitiveness equation are invariant across all models since the same dependent variable is used in all regressions. . *, $* *$ and $* * *$ indicate significance at the $10 \%, 5 \%$ and $1 \%$ levels, respectively.

\section{First-stage regressions for innovation competitiveness and price competitiveness (Eq. (5))}

Table A3: First-stage regressions for innovation competitiveness (Eq. (5))

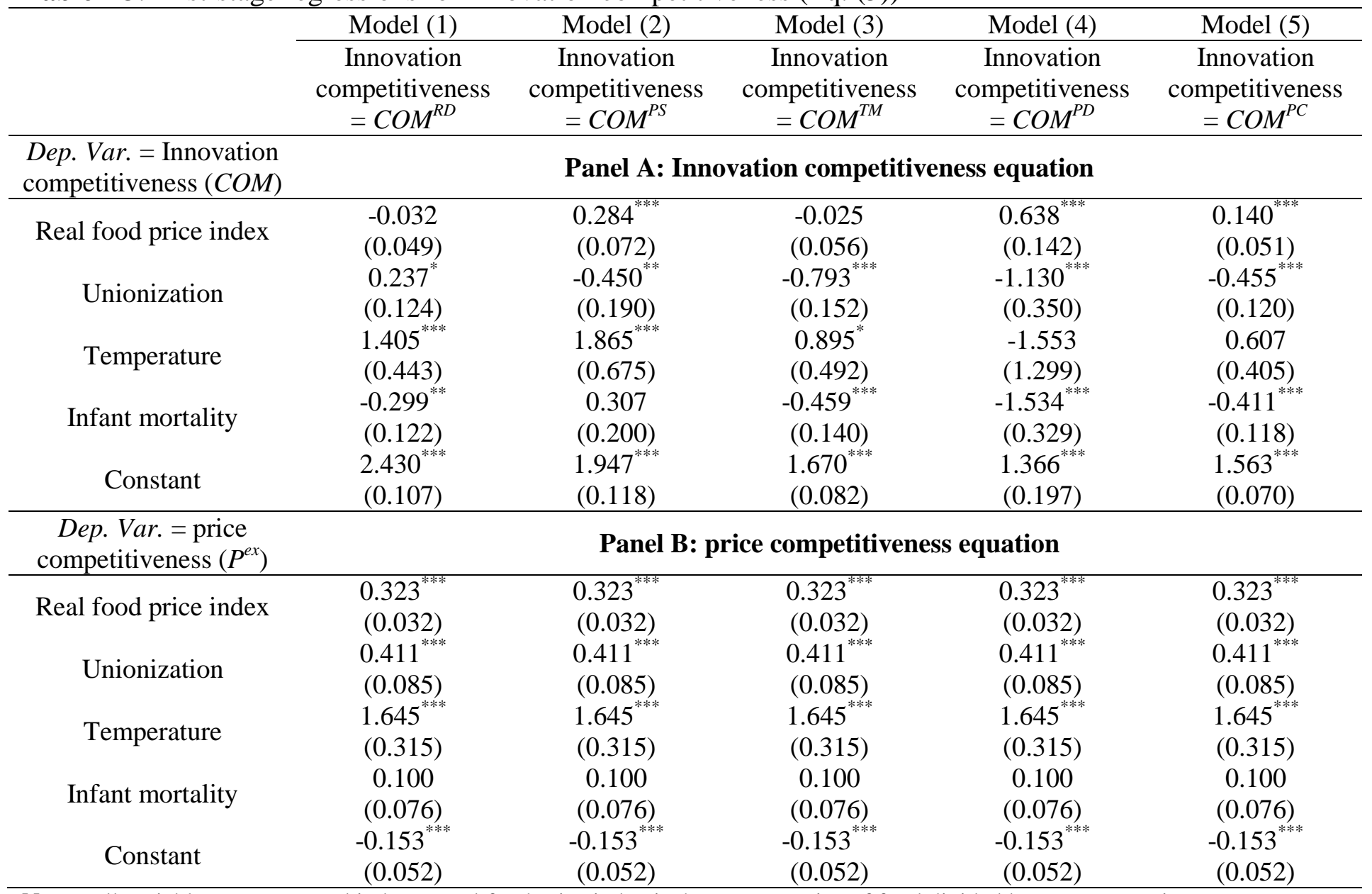

Notes: all variables are measured in logs. Real food price index is the average price of food divided by consumer prices; unionization is the ratio of union membership to total employment; temperature is the average temperature during the year; and infant mortality is the number of infant deaths per 1000 during the first year of life; RD = R\&D stock; PS = patent stock; TM = 
trademark stock; PD = product designs stock; and PC = the first principal component of these four measures. Estimates for the price competitiveness equation are invariant across all models since the same dependent variable is used in all regressions. . *, $* *$ and $* * *$ indicate significance at the $10 \%, 5 \%$ and $1 \%$ levels, respectively.

\section{E: Data sources and definitions of variables}

Export volume $(\boldsymbol{E X})$. Data on total export volume are collected from the following sources. China: various issues of the "China Statistical Yearbook" for data from 1953 to 1979; data after 1979 are obtained from the World Development Indicator CD Rom (2010). India: data for 1953 to 1994 are obtained from the International Financial Statistics CD Rom (2010) whereas those from 1995 are taken from World Development Indicator CD Rom (2010). Japan: International Financial Statistics CD Rom (2010). Korea: data for the period 1953-1963 are collected from various issues of the Korea Statistical Yearbook whereas those after 1963 are taken from the International Financial Statistics CD Rom (2010). Singapore: data for the period 1953-1970 are obtained from "The Economic Growth of Singapore” by W.G. Huff (1971) whereas those from 1971 are obtained from International Financial Statistics CD Rom (2010). Taiwan: various issues of the Taiwan Statistical Data Book.

Trade weighted income (TWI). The trade weights are based on bilateral shares of total exports to the following 26 destinations: Canada, the US, Japan, Australia, New Zealand, Austria, Belgium, Denmark, Finland, France, Germany, Greece, Ireland, Italy, the Netherlands, Norway, Portugal, Spain, Sweden, Switzerland, the UK, China, India, Korea, Singapore, and Taiwan. Real income for each individual country is normalized to have a mean of 1 during the period 1953-2010. The bilateral exports are obtained from the IMF Direction of International Trade Statistics, except for Taiwan where the data are collected from various issues of the Taiwan Statistical Data Book and Statistical Yearbook of the Republic of China.

Real GDP. China: China Statistical Yearbook (various issues) and "Comprehensive Statistical Data and Materials on 50 Years of New China”, Beijing: China Statistics Press. India: National Account Statistics (various issues) and Penn World Table 6.2. Japan: Japan Statistical Yearbook (various issues). Korea: Korea Statistical Yearbook (various issues). Singapore: Yearbook of Statistics Singapore (various issues). Taiwan: Taiwan Statistical Data Book (various issues). For the rest of the countries: OECD, National Accounts, Volume II, Paris: OECD.

Export-GDP ratio in Sub-Saharan Africa. World Development Indicators 2012 Online Database (data retrieved on 03 June 2012), http://data.worldbank.org/data-catalog/world-development-indicators.

\section{Export-GDP ratio across regions. International Monetary Fund, International Financial Statistics.}

Export price competitiveness (EPC). Computed from export unit values in common currency weighed by bilateral export shares to the 26 countries listed under trade weighted income. Real income for each individual country is normalized to have a mean of 1 during the period 1953-2010. The export unit values are domesticcurrency denominated unit values and are converted into a common currency using the exchange rates from IMF, International Financial Statistics. Export unit values are also from IMF, International Financial Statistics except for the following countries. China: "World Tables" by the World Bank for the years 1967-1987; "Statistical Yearbook" by the United Nation for the years 1988-2010. India: "indiastat.com” for the years 1960-2010. Korea: "Statistical Yearbook for Asia and the Pacific 1979" for the years 1963-1966; "World Tables" by the World Bank for the years 1967-1987; "Statistical Yearbook" by the United Nation for the years 1988-2010. Singapore: "World Tables” by the World Bank for the years 1967-1987; "Statistical Yearbook” by the United Nation for the years 1988-2010. Taiwan: "Statistical Yearbook of the Republic of China” for the years 1961-2010. Missing data for the earlier years are estimated by regressing export price index on GDP deflator, CPI and wage index.

R\&D stock (STK $\boldsymbol{R D}^{\boldsymbol{D}}$ ). Real total R\&D expenditures are used in the estimation. Data for 1965-2004 are obtained from OECD Main Science and Technology Indicators, OECD Archive (OECDDSTI/EAS), National Science Foundation and Statistics Netherlands. The data are extrapolated to 2006. Earlier year data are obtained from various sources documented in Madsen (2008b). The data for the Asian countries are obtained as follows. China: China Statistical Yearbook (various issues), "Comprehensive Statistical Data and Materials on 50 Years of New 
China”, Beijing: China Statistics Press, “Statistics on Science and Technology of China: 1949-1989”, Peking: Zhongguo Tong Ji Chu Ban She and the various issues of "S\&T Statistics Data Book" published by the Ministry of Science and Technology. India: various issues of "R\&D Statistics" published by the Department of Science and Technology and "Macro-Aggregates" published by the Planning Commission, Government of India. These data are complemented with various issues of the UNESCO Statistical Yearbook published by the United Nations Educational, Scientific, and Cultural Organization. Data are available at five year intervals between 1950 and 1970, and continuously thereafter. Missing data are interpolated using the geometric growth rate. Japan: Japan Statistical Yearbook (various issues). Korea: Korea Statistical Yearbook (various issues) and UNESCO Statistical Yearbook (various issues). Data before 1967 are predicted using the first principal component of the data for China, India, Japan and Taiwan. Singapore: Yearbook of Statistics Singapore (various issues). UNESCO Statistical Yearbook (various issues). Data before 1970 are predicted using the first principal component of the data for China, India, Japan and Taiwan. Taiwan: Taiwan Statistical Data Book (various issues) and Statistical Yearbook of the Republic of China (various issues). Data before 1970 are estimated using the first principal component of the number of patent applications (obtained from various issues of "Annual Report" and "Yearbook of Intellectual Property" published by the Taiwan Intellectual Property Office (TIPO)), enrolment numbers in science and engineering courses and R\&D data for China and India.

Nominal R\&D expenditure is deflated using an unweighted average of the economy-wide value-added price deflator and hourly earnings, following Coe and Helpman (1995), to express in real terms. Price deflator is obtained from the same domestic sources as GDP (see above). Except for Japan where the data are available from Japan Statistical Yearbook (various issues), hourly earnings data for all other countries are compiled from the "Yearbook of Labour Statistics", Geneva: International Labour Office and other domestic sources described above. For China, data before 1979 are estimated by assuming that the growth rate of wages equals the sum of labor productivity growth and the inflation rate. Real R\&D capital stock is calculated using the perpetual inventory method. The initial R\&D capital stock is obtained by using the Solow model steady-state value of $I_{0} /(\delta+g)$, where $I_{0}$ is initial real investment, $\delta$ is the rate of depreciation and $g$ is the growth rate in real R\&D expenditure over the period for which investment data are first available to 2010.

Patent stock $\left(S T K^{P S}\right)$, trade mark stock $\left(S T K^{T M}\right)$ and product design stock $\left(S T K^{P D}\right)$. Data for Taiwan are obtained from the "Annual Report" and "Yearbook of Intellectual Property" of Taiwan Intellectual Property Office (TIPO). Data for all other countries are collected from the World Intellectual Property Organization (2010). Patent stock and its accompanied competitive measure are derived using the same procedure described above.

Patent stock competitiveness $\left(C O M^{P S}\right)$, trade mark stock competitiveness $\left(C O M^{T M}\right)$ and product design stock competitiveness $\left(\boldsymbol{C O M}^{P D}\right)$. Stocks are normalized to have a mean of 1 for each individual country over the sample period and weighted by bilateral export shares.

Real food prices. For the non-AM economies see Madsen (2012). India: 1950-2005: de Vries and Timmer, 2007, Groningen Growth and Development Centre 10-sector database, June 2007, http://www.ggdc.net/ spliced with Agriculture price index (Agriculture value added current US\$/ Agriculture value added constant 2000 US\$) 2005-2011: World Development Indicators, CPI 1870-2011: Dharma kumar, Meghnad Desai, 1982, The Cambridge Economic History of India 1757-1970, volume 2, Cambridge University Press, spliced with 1940-2005 Mitchell, B. R., 2007. International Historical Statistics: Africa, Asia and Oceania, 1750-2005, $5^{\text {th }}$ Ed. Palgrave Macmillan, New York spliced with 2005-2011 International Financial Statistics. Korea: Agriculture price index 1953-1965: de Vries and Timmer, 2007, Groningen Growth and Development Centre 10-sector database, June 2007, http://www.ggdc.net/spliced with Agriculture price index (Agriculture value added current US\$/ Agriculture value added constant 2000 US\$) 1965-2011: World Development Indicator, CPI Mitchell, Africa, Asia and Oceania, 2007, op cit. updated using IMF, International Financial Statistics. Singapore: 1947-1960: Ichiro Sugimoto, 2011, Economic Growth of Singapore in the Twentieth Century, Historical GDP Estimates and Empirical Investigations, World Scientific Publishing Co. Pte. Ltd. Food price index 
1961-1970 interpolated. Agriculture price index 1971-1975: de Vries and Timmer, 2007 op cit. spliced with Agriculture price index (Agriculture value added current US\$/ Agriculture value added constant 2000 US\$) 1975-2011: World Development Indicator, CPI: 1953-1961 Ichiro Sugimoto, 2011, op cit. spliced with 1961-2005 Mitchell, Africa, Asia and Oceania, 2007, op cit., spliced with 2005-2011 IMF, International Financial Statistics. Taiwan: Agriculture price index 1961-1981: de Vries and Timmer, 2007 op cit. spliced with food price index 1981-2011: Taiwan Statistical year book 2011, CPI 1953-2011: Mitchell, 2007, Africa, Asia and Oceania, op cit. spliced with Taiwan Statistical Data Book 2012, downloaded from: http://www.cepd.gov.tw/encontent/m1.aspx?sNo=0017349.

Temperature. Tyndall Centre for Climate Change Research (http://www.cru.uea.ac.uk/ timm/index.html).

Infant mortality. For the non-AM economies see Madsen (2013). The following sources are used for the AM economies. Korea. 1900-1930: Chesnais, Jean-Claude, 1992, “The demographic transition: Stages, Patterns and Economic Implications” (Clarendon Press, Oxford). 1930-1953: Decreasing Trends of Neonatal and Infant Mortality Rates in Korea: Compared with Japan, USA, and OECD Nations, 2011, J Korean Medical Science, 26:1115-1123. 1953-2011: UNICEF, (http://www.childmortality.org). India. 1872-1911: Gupta, P.D., 1971, "Estimation of Demograhpic Measures for India, 1881-1961, Based on Census Age Distributions", Population Studies, 25(3), 395-414. 1953-2011: UNICEF, (http://www.childmortality.org). Singapore. 1900-1926: Y Otaki, M Otaki and O Sakura, 2007, "Water Systems and Urban Sanitation: A Historical Comparison of Tokyo and Singapore," Journal of Water and Health, 259-265. 1930-1953: UN Demographic Yearbook 1966, Table 14, Page 290. 1930 to 1954 Mitchell (1941 and 1942 are interpolated); 1955 to 2011: childmortality.org downloaded 12.1.12. Taiwan. 1920-1957: Chesnais, Jean-Claude, 1992, “The demographic transition: Stages, Patterns and Economic Implications” (Clarendon Press, Oxford). 1953-2011: UNICEF (http://www.childmortality.org). China. 1928-1929: Notestein, F.W. and Chiao, C.-M., 1937, “Population”, in J.L. Buck (ed.), Land Utilization in China, Nanking: University of Nanking, 358-399. 1970-2011: UNICEF (http://www.childmortality.org).

Patent protection index. Park (2008).

Regional trade agreements. Baier and Bergstrand (2007).

Tariff rates. Data on tariffs and imports are collected from the following sources. China: China Statistical Yearbook (various issues) and "Comprehensive Statistical Data and Materials on 50 Years of New China”, Beijing: China Statistics Press. India: National Account Statistics (various issues) and Penn World Table 6.2. Japan: Japan Statistical Yearbook (various issues). Korea: Korea Statistical Yearbook (various issues). Singapore: Yearbook of Statistics Singapore (various issues). Taiwan: Taiwan Statistical Data Book (various issues). Some data before 1990 are obtained from Mitchell, B.R. (2008), "International Historical Statistics: Asia and Africa (London: Macmillan)”. For the other countries see Madsen (2009b).

Polity 2. Polity 2 is given as the difference between the degree of democracy and autocracy, where a higher value reflects the presence of a more democratic regime. Source: Polity IV Project, Marshall and Jaggers (2010).

Union membership. Visser, J (2013), ICTWSS Database on Institutional Characteristics of Trade Unions, Wage Setting, State Intervention and Social Pacts in 34 countries between 1960 and 2012, Amsterdam Institute for Advanced Labour Studies, AIAS, University of Amsterdam, and International Labour Organisation (ILO) (http://laborsta.ilo.org/xls data_E.html), Ross, Arthur M. and Paul T. Hartman. 1960 Changing Patterns of Industrial Conflict, New York and London: John Wiley \& Sons, Table 1A, George S Bain and Robert Price, Profiles in Union Growth, 1980, Basil Blackwell, Oxford. China: data from 1965 to 1979 are taken from Visser, J (2013), op cit.. Data since 1980 are taken from International Labour Organisation (ILO) (http://laborsta.ilo.org/xls data E.html). India: International Labour Organisation (ILO) for the years 1980-1999; Statistical Yearbook India (2013) for the years 2000-2010. Japan: "Historical Statistics of Japan (First Edition)" (Japan Statistical Association) for the years 1953-1962; OECD.Stat database for the years 1963-2010. Korea: 
OECD.Stat database for the years 1963-2010. Singapore: Visser, J (2013) for the years 1960-1979; International Labour Organisation (ILO) for the years 1980-2010. Taiwan: International Labour Organisation (ILO) for the years 1987-2010.

Employment. China: data for the period 1953-1976 are taken from Maddison, A (2007), "Chinese Economic Performance in the Long Run, 960-2030 AD”, Second Edition, Revised and Updated (OECD, Paris); data from 1977 to 2005 are obtained from International Labour Organisation (ILO); data since 2005 are from China Statistical Yearbook (2011, 2012). India: data before 1985 are obtained from Mitchell, B.R. (2008), "International Historical Statistics: Asia and Africa (London: Macmillan)” and some missing data are interpolated; data for the years 1985 to 1999 are from - International Financial Statistics (IFS); data since 2000 are from Statistical Yearbook India (2013). Japan: Japan Statistical Yearbook (various issues). Korea: OECD.Stat database for the years 19692006; Korea Statistical Yearbook for the years 2007-2010. Singapore: Mitchell, B.R. (2008), "International Historical Statistics: Asia and Africa (London: Macmillan)" for the years 1953-1972; International Labour Organisation (ILO) for the years 1973-2000; Yearbook of Statistics Singapore $(2007,2012)$ for the years 20012010 (2007, 2012). Taiwan: Taiwan Statistical Data Book (various issues). Missing data are extrapolated. For the other countries see Madsen (2008b, 2009b).

Age distribution of population. The population distributions are classified according to the following age groups: 0-4, 5-9, 10-14, 15-19, 20-24, 25-29, 30-34, 35-39, 40-44, 45-49, 50-54, 55-59, 60-64, 65-69, 7074, 75-79, 80+. Principal data sources used were Mitchell (2007) and the UN (2012) database, http://esa.un.org/wpp/Excel-Data/population.htm, accessed on $15^{\text {th }}$ of March 2013. China. 1870-1950 was backdated using age distributions from India as proxy country and total population from Maddison (2010) . 1951-2010 data was obtained from the UN database. The backdated series from 1870-1950 was then spliced to the level of the UN series using 1951 as base year. 2011 was obtained by growth extrapolation. India.1870 was backdated using total population from Maddison (2010) and age distributions from 1881 as proxy. 1881, 1891, 1901, 1911, 1921, 1931, 1951, 1961, 1971, 1981, 1993 and 2001 population by age groups was obtained from Mitchell (2007). The 60-64, 65-69, 70-74, 75-79, 80+ age group data for 1881, 1891 and 1901 was obtained by decomposing Mitchell (2007)'s combined age groups data using 1911 age distributions. Similarly, the 70-74, 75-79, 80+ populations were obtained using 1961 age distributions as proxy. The intervening years within the census data were growth interpolated. 2002-2010 is from the UN database, while 2011 was obtained using 2010 age distributions and Maddison (2010)'s total population data which was growth extrapolated to 2011. Singapore. 1870-1949 was backdated using age distributions from India as proxy and total population from Maddison (2010). 1950-2010 is from the UN database. 2011 was obtained using 2010 age distributions and Maddison (2010)'s total population which was growth extrapolated to 2011. Korea. 1870-1929 was backdated using age distributions from India as proxy and total population from Maddison (2010). 1930, 1944, 1960, 1975, 1980 and 1994 census data was obtained from Mitchell (2007). The 1870-1929 backdated data was then spliced to the level census data using 1930 as base year. 1995-2010 is from the UN database. 2011 was obtained using 2010 age distributions and Maddison (2010)'s total population which was growth extrapolated to 2011. All intervening years were growth interpolated. Taiwan. 1870-1904 was backdated using age distributions from India as proxy and total population from Maddison (2010). 1905, 1915, 1920, 1930, 1940, 1956 , 1966, 1970 and 1980 census data was obtained from Mitchell (2007). The backdated 1870-1904 data was then spliced to the level of census data using 1905 as base year. The 70-74, 75-79 age group data for 1905, 1915 and 1920 was obtained by decomposing Mitchell (2007)'s age groups using the 1940 age distributions as proxy. The 70-74, 75-79 and 80+ data for 1970, as well as the 70-74, 75-79 populations for 1980 were also computed using age distributions from 1966 as proxy. 1981-2011 was obtained using age distributions from India as proxy and total population from Maddison (2010). This was subsequently spliced to the level of actual census data using 1980 as base year. All intervening years were growth interpolated. 


\section{References}

Almond, D. \& J. Currie (2011) 'Killing Me Softly: The Fetal Origins Hypothesis', Journal of Economic Perspectives, 25, 153-72

Amable, B. \& B. Verspagen (1995) 'The Role of Technology in Market Shares Dynamics', Applied Economics, 27, 197-204

Amendola, G., G. Dosi \& E. Papagni (1993) 'The Dynamics of International Competitiveness', Weltwirtschaftliches Archiv, 129, 451-71

Anderson, J. E. (2011) 'The Gravity Model', Annual Review of Economics, Annual Reviews, 3, 133-60

Anderton, B. (1999a) 'Innovation, Product Quality, Variety, and Trade Performance: An Empirical Analysis of Germany and the UK', Oxford Economic Papers, 51, 152-67

Anderton, B. (1999b) 'UK Trade Performance and the Role of Product Quality, Innovation and Hysteresis: Some Preliminary Results', Scottish Journal of Political Economy, 46, 553-70

Baier, S. L. \& J. H. Bergstrand (2001) 'The Growth of World Trade: Tariffs, Transport Costs, and Income Similarity', Journal of International Economics, 53, 1-27

Baier, S. L. \& J. H. Bergstrand (2007) 'Do Free Trade Agreements Actually Increase Members' International Trade?', Journal of International Economics, 71, 72-95

Baldwin, R. \& J. Lopez-Gonzalez (2013) 'Supply-chain Trade: A Portrait of Global Patterns and Several Testable Hypotheses', NBER Working Paper 18957,

Bruno, M. \& J. D. Sachs (1985) Economics of Worldwide Stagflation. (Cambridge, MA: Harvard University Press)

Carlin, W., A. Glyn \& J. V. Reenen (2001) 'Export Market Performance of OECD Countries: An Empirical Examination of the Role of Cost Competitiveness', Economic Journal, 111, 128-62

Castilho, S. D. \& A. A. Barros Filho (2010) 'The History of Infant Nutrition', Jornal de Pediatria, 86, 179-88

Choi, I. (2001) 'Unit Root Tests for Panel Data', Journal of International Money and Finance, 20, 249-72

Coe, D. T. \& E. Helpman (1995) 'International R\&D spillovers', European Economic Review, 39, 859-97

Costinot, A. (2009) 'On the Origins of Comparative Advantage', Journal of International Economics, 77, 255-64

Easterly, W. (1994) 'Explaining miracles : growth regressions meet the Gang of Four', The World Bank Policy Research Working Paper No. 1250,

Eppig, C., C. L. Fincher \& R. Thornhill (2010) 'Parasite Prevalence and the Worldwide Distribution of Cognitive Ability', Proceedings of the Royal Society B: Biological Sciences, 77, 3801-08

Ethier, W. J. (1982) 'National and International Returns to Scale in the Modern Theory of International Trade', American Economic Review, 72, 389-405

Fagerberg, J., M. Srholec \& M. Knell (2007) 'The Competitiveness of Nations: Why Some Countries Prosper While Others Fall Behind', World Development, 35, 1595-620

Fagerberg, J. E. (1988) 'International Competitiveness', Economic Journal, 98, 355-74

Fagerberg, J. E. (1994) 'Technology and International Differences in Growth Rates', Journal of Economic Literature, 32, 1147-75

Fagerberg, J. E. (1996) 'Technology and Competitiveness', Oxford Review of Economic Policy, 12, 39-51

Fagerberg, J. E. (1997) 'Competitiveness, Scale, and R\&D', in Technology and International Trade, eds. J. Fagerberg, P. Hansson, L. Lundberg and A. Melchior (Cheltenham: Edward Elgar)

Goerke, L. (2002) Taxes and Unemployment: Collective Bargaining and Efficiency Wage Models. (Boston, Dordrecht und London: Kluwer Academic Publishers)

Goerke, L. \& M. Pannenberg (2004) 'Norm-Based Trade Union Membership: Evidence for Germany', German Economic Review, 5, 481-504

Goldstein, M. \& M. S. Khan (1985) 'Income and Price Effects in Foreign Trade', in Handbook of International Economics, edition 1, volume 2, eds. R. W. Jones and P. B. Kenen: Elsevier)

Greenhalgh, C. (1990) 'Innovation and Trade Performance in the United Kingdom', Economic Journal, 100, 105-18

Greenhalgh, C., P. Taylor \& B. Wilson (1994) 'Innovation and Export Volumes and Prices - A Disaggregated Study', Oxford Economic Papers, 46, 102-34

Griliches, Z. (1990) 'Patent Statistics as Economic Indicators: A Survey', Journal of Economic Literature, 28, 1661-707

Grossman, G. M. \& E. Helpman (1991) Innovation and Growth in the Global Economy. (Cambridge: MIT Press) 
Gustafsson, P. \& P. Segerstrom (2010) 'North-South Trade with Increasing Product Variety', Journal of Development Economics, 92, 97-106

Hanson, G. H. (2012) 'The Rise of Middle Kingdoms: Emerging Economies in Global Trade', nber WORKING Paper 17961,

Helpman, E. \& P. R. Krugman (1985) Market Structure and Foreign Trade: Increasing Returns, Imperfect Competition, and the International Economy. (Cambridge, Massachusetts: MIT Press)

Holliday, M. (1986) 'Body Composition and Energy Needs during Growth', in Human Growth: A Comprehensive Treatise, 2, eds. F. Falkner and J. M. Tanner (New York: Plenum)

Jardim-Botelho, A., S. Raff, R. Rodgrigues, H. Hoffman, D. Diemert, R. Correa-Oliveira, J. Bethony \& M. Gazzinelli (2008) 'Hookworm, Ascaris Lumbricoides Infection and Polyparasitism Associated with Poor Cognitive Performance in Brazilian Schoolchildren', Tropical Medicine and International Health, 13, 9941004

Johansen, S. (1995) Likelihood-Based Inference in Cointegrated Vector Autoregressive Models. (Oxford: Oxford University Press)

Jongwanich, J. (2010) 'Determinants of Export Performance in East and Southeast Asia', World Economy, 33, 20 41

Kao, C. (1999) 'Spurious Regression and Residual-Based Tests for Cointegration in Panel Data', Journal of Econometrics, 90, 1-44

Kao, C. \& M.-H. Chiang (2000) 'On the Estimation and Inference of A Cointegrated Regression in Panel Data', in Nonstationary Panels, Panel Cointegration, and Dynamic Panels (Advances in Econometrics), ed. B. Baltagi (New York: Elsevier Science)

Krugman, P. R. (1989) 'Differences in Income Elasticities and Trends in Real Exchange Rates', European Economic Review, 33, 1031-49

Lee, K. S. (2007) 'Infant Mortality Decline in the Late 19th and Early 20th Centuries: The Role of Market Milk', Perspectives in Biology and Medicine, 50, 585-602

Levchenko, A. A. (2007) 'Institutional Quality and International Trade', Review of Economic Studies, 74, 791-819

Linden, G., K. L. Kraemer \& J. Dedrick (2009) 'Who Captures Value In A Global Innovation Network? The Case of Apple's iPod', Communications of the ACM, 52, 140-44

Lucas, R. E., Jr (1993) 'Making a Miracle', Econometrica, 61, 251-72

Lynn, R. \& T. Vanhanen (2006) IQ and Global Inequality. (Augusta: Washington Summit Publishers)

Maddala, G. S. \& S. Wu (1999) 'A Comparative Study of Unit Root Tests with Panel Data and A New Simple Test', Oxford Bulletin of Economics and Statistics, 61, 631-52

Maddison, A. (2010) Historical Statistics of the World Economy: 1-2008 AD (http://www.ggdc.net/maddison/).

Madsen, J. B. (1998a) 'Errors-in-variables, Supply Side Effects, and Price Elasticities in Foreign Trade', Review of World Economics, 134, 612-37

Madsen, J. B. (1998b) 'General Equilibrium Macroeconomic Models of Unemployment: Can They Explain the Unemployment Path in the OECD?', Economic Journal, 108, 850-67

Madsen, J. B. (1999) 'On Errors in Variable Biases in Estimates of Export Price Elasticities', Economics Letters, 63, 313-19

Madsen, J. B. (2008a) 'Innovations and Manufacturing Export Performance in the OECD Countries', Oxford Economic Papers, 60, 143-67

Madsen, J. B. (2008b) 'Semi-Endogenous versus Schumpeterian Growth Models: Testing the Knowledge Production Function using International Data', Journal of Economic Growth, 13, 1-26

Madsen, J. B. (2009a) 'The Dynamics of Labour'S Income Shares And The Wage Curve-Phillips Curve Controversy', Scottish Journal of Political Economy, 56, 45-72

Madsen, J. B. (2009b) 'Trade Barriers, Openness, and Economic Growth', Southern Economic Journal, 76, 397-418

Madsen, J. B. (2012) 'Health, Human Capital Formation and Knowledge Production: Two Centuries of International Evidence', NBER Working Paper no. 18461,

Madsen, J. B. (2013) 'Health, IQ, and Growth in the Industrialized Countries Over the Past Two Centuries', Mimeo, Monash University,

Magnier, A. \& J. Toujas-Bernate (1994) 'Technology and Trade: Empirical Evidences for the Major Five Industrialized Countries', Weltwirtschaftliches Archiv, 130, 494-520 
Malanima, P. (2006) 'Energy Crisis and Growth 1650-1850: The European Deviation in a Comparative Perspective', Journal of Global History, 1, 101-21

Mansfield, E. D., H. V. Milner \& B. P. Rosendorff (2002) 'Why Democracies Cooperate More: Electoral Control and International Trade Agreements', International Organization, 56, 477-513

Mark, N. C. \& D. Sul (2003) 'Cointegration Vector Estimation by Panel DOLS and Long-run Money Demand', Oxford Bulletin of Economics and Statistics, 65, 655-80

Marshall, M. G. \& K. Jaggers (2010) 'Polity IV Project', Center for International Development and Conflict Management, University of Maryland,

Niehaus, M., S. Moore, P. Patrick, L. Derr, B. Lorntz, A. Lima \& R. Guerrant (2002) 'Early Childhood Diarrhea is Associated with Diminished Cognitive Function 4 to 7 Years Later in Children in a Northeast Brazilian Shantytown', American Journal of Tropical Medical Hygiene, 66, 590-93

Park, W. G. (2008) 'International patent protection: 1960-2005', Research Policy, 37, 761-66

Pedroni, P. (1999) 'Critical Values for Cointegration Tests in Heterogeneous Panels with Multiple Regressors', Oxford Bulletin of Economics and Statistics, 61, 653-70

Pedroni, P. (2000) 'Fully-modified OLS for Heterogeneous Cointegrated Panels', in Nonstationary Panels, Panel Cointegration, and Dynamic Panels (Advances in Econometrics), ed. B. Baltagi (New York: Elsevier Science)

Pedroni, P. (2001) 'Purchasing Power Parity Tests in Cointegrated Panels', review of Economics and Statistics, 83, 727-31

Pedroni, P. (2004) 'Panel Cointegration: Asymptotic and Finite Sample Properties of Pooled Time Series Tests with an Application to the PPP Hypothesis', Econometric Theory, 20, 597-625

Phillips, P. C. B. \& B. Hansen (1990) 'Statistical Inference in Instrumental Variables Regression with I(1) Processes', Review of Economic Studies, 57, 99-125

Puga, D. \& D. Trefler (2010) 'Wake Up and Smell the Ginseng: International Trade and the Rise of Incremental Innovation in Low-wage Countries', Journal of Development Economics, 91, 64-76

Radelet, S., J. Sachs \& J.-W. Lee (2001) 'The Determinants and Prospects of Economic Growth in Asia', International Economic Journal, 15, 1-29

Redding, S. \& A. J. Venables (2003) 'South-East Asian Export Performance: External Market Access and Internal Supply Capacity', Journal of the Japanese and International Economies, 17, 404-31

Rodrik, D. (1996) 'Coordination Failures and Government Policy: A Model with Applications to East Asian and Eastern Europe', Journal of International Economics, 40, 1-22

Rodrik, D. (1997) 'The 'Paradoxes' of the Successful State', European Economic Review, 42, 411-42

Romer, P. M. (1990) 'Endogenous Technological Change', Journal of Political Economy, 98, S71-102

UN (2012) 'World Population Prospects: The 2012 Revision', United Nations Online dataset (http://esa.un.org/wpp/Excel-Data/population.htm),

Wagner, M. \& J. Hlouskova (2010) 'The Performance of Panel Cointegration Methods: Results from a Large Scale Simulation Study', Econometric Reviews, 29, 182-223

Watkins, W. \& E. Pollitt (1997) '‘Stupidity or Worms’: Do Intestinal Worms Impair Mental Performance?', Psychological Bulletin, 121, 171-91

Wolff, E. N. (1995) 'Technological Change, Capital Accumulation, and Changing Trade Patterns over the Long Term', Structural Change and Economic Dynamics, 6, 43-70 